This item was submitted to Loughborough's Research Repository by the author.

Items in Figshare are protected by copyright, with all rights reserved, unless otherwise indicated.

\title{
The impact of oil shocks in a small open economy new-Keynesian dynamic stochastic general equilibrium model for an oil-importing country: The case of South Africa
}

\section{PLEASE CITE THE PUBLISHED VERSION}

https://doi.org/10.1080/1540496X.2018.1474346

\section{PUBLISHER}

(C) Taylor \& Francis

\section{VERSION}

AM (Accepted Manuscript)

\section{PUBLISHER STATEMENT}

This is an Accepted Manuscript of an article published by Taylor \& Francis in Emerging Markets Finance and Trade on 26 September 2018, available online: http://www.tandfonline.com/10.1080/1540496X.2018.1474346.

\section{LICENCE}

CC BY-NC-ND 4.0

\section{REPOSITORY RECORD}

Hollander, Hylton, Rangan Gupta, and Mark Wohar. 2018. "The Impact of Oil Shocks in a Small Open Economy New-keynesian Dynamic Stochastic General Equilibrium Model for an Oil-importing Country: The Case of South Africa". figshare. https://hdl.handle.net/2134/35671. 


\title{
The Impact of Oil Shocks in a Small Open Economy New-Keynesian Dynamic Stochastic General Equilibrium Model for an Oil-Importing Country: The Case of South Africat
}

\begin{abstract}
This paper studies the effects of foreign (real) oil price shocks on key macroeconomic variables for South Africa: a net-importer of oil. We develop and estimate a small open economy New Keynesian dynamic stochastic general equilibrium model with a role for oil in consumption and production. The substitutability of oil for capital and consumption goods is low, import price pass-through is incomplete, domestic and foreign prices and wages are sticky, and the uncovered interest rate parity condition holds imperfectly. Foreign real oil price shocks have a strong and persistent effect on domestic production and consumption activities and, hence, are a fundamental driver of output, inflation and interest rates in both the short- and long-run. Oil price shocks also generate a trade-off between output and inflation stabilisation. As a result, episodes of endogenous tightening of monetary policy slow the recovery of South Africa's real economy. Our findings go further to suggest an important role for oil prices in predicting South African output during and after the recession that followed the 2008 global financial crisis.
\end{abstract}

Keywords: Oil shocks, small open economy, DSGE model, South Africa JEL: E31, E32, E37, E52, Q43

\section{Introduction}

Following the early works of Rasche and Tatom (1977), Mork and Hall (1980), Hamilton (1983), and Hickman et al. (1987), which investigated the effects of oil shocks on the business cycles in the United States, a large international literature exists that has analyzed the impact of oil price shocks on macroeconomic variables for both developing and developed economies (see for example, Cunado and Perez de Gracia, 2003, 2005: Jiménez-Rodríguez and Sánchez, 2005; Cologni and Manera, 2008, 2009; Baumeister et al., 2010; Sánchez, 2011; Gupta and Wohar, 2017, for detailed literature reviews in this regard). Within the set of emerging economies considered, South Africa - an oil importing and inflation targeting small open economy - has featured prominently. A large number of studies have been devoted to analysing the impact of oil shocks on macroeconomic variables of the South African economy

\footnotetext{
${ }^{\star}$ We would like to thank two anonymous referees for many helpful comments. However, any remaining errors are solely ours.
} 
(see for example, Dagut, 1978; Kantor and Barr, 1986; McDonald and van Schoor, 2005; Bellamy, 2006; Kohler, 2006; Nkomo, 2006; Swanepoel, 2006; Wakeford, 2006, 2012; Fofana et al., 2009; Gupta and Hartley, 2013; Aye et al., 2014, 2017; Balcilar et al., 2017, 2018; Kin and Courage, 2014; Ajmi et al., 2015; de Bruyn et al., 2015; Gupta and Kanda, 2015; Tshepo, 2015; Chisadza et al., 2016; Gupta and Kotze, 2017). In general, these studies tend to agree with the fact that oil shocks are inflationary for the South African economy. However, the impact of oil shocks on the other variables are exceptionally mixed; ranging from positive to negative, and even neutral (in the statistical sense) depending on the methodology, variables and the sample periods considered.

All these studies rely on macroeconometric models comprising of either (linear or nonlinear) regressions and variations of vector autoregressive (VAR) or vector error-correction (VEC) frameworks. These types of models involve only a few variables and therefore tend to be misspecified (Paetz and Gupta, 2016), and hence, the results from these studies could be biased and probably differ from the true magnitude of the effects of oil price shocks (Gupta and Sun, 2016). In fact, unless a general equilibrium approach is considered, these effects could possibly end up being overestimated (Hou et al., 2016). Further, with these approaches being atheoretical and non-structural, they suffer from the Lucas (1976) critique. Being not microfounded and not grounded in proper theory could also be the reason behind the mixed macroeconomic evidence as reported in the above-discussed South African literature involving oil price shocks. Using a theoretical framework helps identify channels through which oil price affects the economy, quantify its importance, and also provide recommendations for policy-makers, especially central bankers. In addition, recent studies by Paetz and Gupta (2016) and Gupta and Sun (2016), while analysing the impact of stock and house prices on the South African economy, show that results based on atheoretical frameworks tend to be overstated relative to those obtained under microfounded dynamic stochastic general equilibrium (DSGE) models.

Against this backdrop, we develop a small open economy New Keynesian DSGE (SOENKDSGE) model for South Africa with a role for oil in household consumption and firm production activities. In production, we emphasise capital-oil substitutability (e.g., Kim and Loungani (1992), Rotemberg and Woodford (1996), Backus and Crucini (2000), Frondel and Schmidt (2002, 2004)) rather than between labour and oil as in Medina and Soto (2005) and Blanchard and Riggi (2013). The substitutability of oil for physical capital and consumption goods is low. We assume that the law of one price does not hold for foreign goods and oil so that import price pass-through is incomplete (Burstein and Gopinath, 2014). The domestic economy follows the standard New Keynesian setup with nominal price and wage stickiness. Similar to Medina and Soto (2005) and Steinbach et al. (2009), in a world of complete asset markets we have complete international risk sharing in consumption. Importantly, stochastic risk premiums on both domestic and foreign assets means that the uncovered interest parity condition holds imperfectly. We estimate the model for the South African economy over the period 1995:Q1-2017:Q2. The foreign economy macroeconomic data are aggregated and weighted according to major trading partners. Using this model, we study the role of foreign (real) oil price shocks on output, inflation, the nominal interest rate and exchange rates. The relationship between the real oil price and South African recessions are shown in Figure1. As 


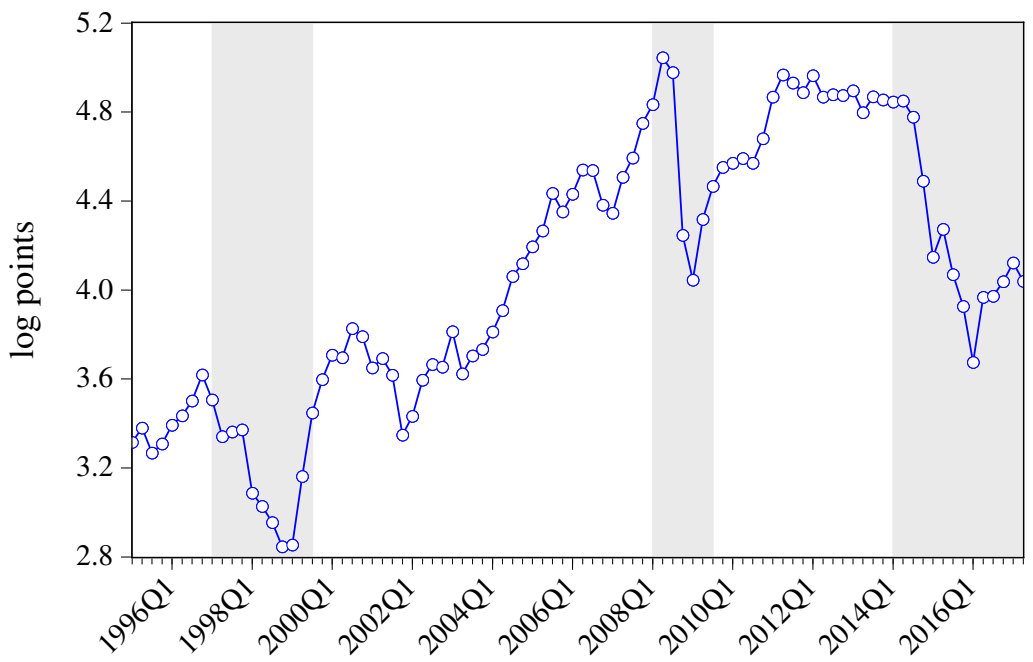

Figure 1: Log of the foreign real price of oil

(Shaded areas indicate downward phases of the South African business cycle)

can be seen, the real oil price tends to be on the rise leading up to each recession, followed by a sharp drop. The most severe episode occurred over the 2008:Q1-2009:Q3 recession period. Here, a $23 \%$ positive real oil price shock in the second quarter of 2008 likely worsened the downturn.

We also compare alternative models with and without oil to highlight the importance of endogenous oil price and quantity dynamics, as well as the model's relative forecast performance. To the best of our knowledge this is the first paper to develop a SOE-NKDSGE model for South Africa with an explicit role for oil (energy) usage. In the process, we add to the fast growing international literature on DSGE models that incorporate oil shocks (Kilian, 2014), and particularly to the small number of papers that exists on oil shocks in DSGE models for small open oil importing countries (see for example, Medina and Soto, 2005; An and Kang, 2011; Beidas-Strom and Poghosyan, 2011; Alba et al., 2013).

The remainder of the paper is organized as follows. Section 2 develops the small open economy New Keynesian DSGE model wherein oil forms part of the representative household's consumption basket and enters as a factor input in firm production. Section 3 discusses the data and calibration of the model as well as the Bayesian estimation results. Section 4 present results for two alternative models: a SOE-NKDSGE model with oil versus one without. In Sub-Section 4.1 we show both the historical and variance decomposition of output, inflation and the nominal interest rate to investigate the importance of oil price shocks. Sub-Section 4.2 compares impulse response functions on key macroeconomic variables. To provide some additional insight on the merits of the model with oil, Sub-Section 4.3 concludes our comparison analysis with out-of-sample forecasts for output, inflation and the nominal interest rate. Finally, Section 5 concludes. 


\section{The model}

\subsection{Domestic households}

The domestic economy is populated by a continuum of infinitely lived households, indexed by $j \in[0,1]$. Each household $j$ 's consumption bundle is given by

$$
C_{j, t}=\left[\left(1-\gamma_{o}\right)^{\frac{1}{\eta_{o}}}\left(Z_{j, t}\right)^{\frac{\eta_{o}-1}{\eta_{o}}}+\gamma_{o}^{\frac{1}{\eta_{o}}}\left(O_{j, t}^{c}\right)^{\frac{\eta_{o}-1}{\eta_{o}}}\right]^{\frac{\eta_{o}}{\eta_{o}-1}},
$$

where the composite consumption index is a constant elasticity of substitution (CES) function consisting of fuel (oil) consumption $O_{j, t}^{c}$ and non-fuel (goods) consumption $\left(Z_{j, t}\right)$. In addition, households consume both domestic and foreign (imported) consumption goods, given by

$$
Z_{j, t}=\left[\left(1-\gamma_{c}\right)^{\frac{1}{\eta_{c}}}\left(C_{j, t}^{h}\right)^{\frac{\eta_{c}-1}{\eta_{c}}}+\gamma_{c}^{\frac{1}{\eta_{c}}}\left(C_{j, t}^{f}\right)^{\frac{\eta_{c}-1}{\eta_{c}}}\right]^{\frac{\eta_{c}}{\eta_{c}-1}}
$$

where $C_{j, t}^{h}$ and $C_{j, t}^{f}$ represent consumption of domestic and foreign goods. $0 \leq \gamma_{c}, \gamma_{o}<$ 1 capture the import shares of foreign goods and oil. $\eta_{c}$ and $\eta_{o}$ measure the respective intratemporal elasticities of substitution. Each household $j$ chooses her desired combination of oil and core consumption, and domestic and foreign consumption. Minimizing the total cost of each consumption basket subject to Eq. 1 and Eq. 2 gives the demand functions for $Z_{j, t}, O_{j, t}^{c}, C_{j, t}^{h}$, and $C_{j, t}^{f} t_{1}^{1}$

$$
\begin{aligned}
Z_{j, t} & =\left(1-\gamma_{o}\right)\left(\frac{P_{t}^{z}}{P_{t}}\right)^{-\eta_{o}} C_{j, t}, \quad O_{j, t}^{c}=\gamma_{o}\left(\frac{P_{t}^{o}}{P_{t}}\right)^{-\eta_{o}} C_{j, t} \\
C_{j, t}^{h} & =\left(1-\gamma_{c}\right)\left(\frac{P_{t}^{h}}{P_{t}^{z}}\right)^{-\eta_{c}} Z_{j, t}, \quad C_{j, t}^{f}=\gamma_{c}\left(\frac{P_{t}^{f}}{P_{t}^{z}}\right)^{-\eta_{c}} Z_{j, t},
\end{aligned}
$$

where $P_{t}^{h}$ and $P_{t}^{f}$ are the price indices for domestic and foreign goods, and where $P_{t}^{z}$ and $P_{t}^{o}$ are the price of core consumption goods and the price of oil given by

$$
\begin{gathered}
P_{t} \equiv\left[\left(1-\gamma_{o}\right)\left(P_{t}^{z}\right)^{1-\eta_{o}}+\gamma_{o}\left(P_{t}^{o}\right)^{1-\eta_{o}}\right]^{\frac{1}{1-\eta_{o}}} \\
P_{t}^{z} \equiv\left[\left(1-\gamma_{c}\right)\left(P_{t}^{h}\right)^{1-\eta_{c}}+\gamma_{c}\left(P_{t}^{f}\right)^{1-\eta_{c}}\right]^{\frac{1}{1-\eta_{c}}},
\end{gathered}
$$

Household preferences are separable in consumption, labour $N_{j, t}$ and real money balances

\footnotetext{
${ }^{1}$ The households decision problem can be characterised by three stages. (1) each household $j$ minimizes the total cost of its consumption basket, $P_{t}^{z} Z_{j, t}+P_{t}^{o} O_{j, t}^{c}$ subject to Eq. 1. where $P_{t}^{z}$ and $P_{t}^{o}$ are the price of core consumption goods (i.e., the core consumption deflator) and the price of oil; (2) similarly, we minimize the core consumption basket, $P_{t}^{h} C_{j, t}^{h}+P_{t}^{f} C_{j, t}^{f}$ subject to Eq. 2; and (3) we maximise utility subject to the budget constraint.
} 
$\mathcal{M}_{j, t} / P_{t}$, such that each household $j$ maximises their discounted lifetime utility function

$$
E_{0} \sum_{t=0}^{\infty} \beta^{t}\left[\frac{\left(C_{j, t}-\phi C_{t-1}\right)^{1-\sigma_{c}}}{1-\sigma_{c}}-\frac{\left(N_{j, t}\right)^{1+\sigma_{n}}}{1+\sigma_{n}}+\frac{a}{\sigma_{m}}\left(\frac{\mathcal{M}_{j, t}}{P_{t}}\right)^{\sigma_{m}}\right]
$$

where $\beta^{t}$ is the subjective discount factor. The coefficient of relative risk aversion $\sigma_{c}$ measures the curvature of the household's utility function with respect to its argument $C_{j, t}-\phi C_{t-1}$, where $C_{j, t}$ is real consumption at time $t$ and external habit formation is parameterized by $\phi . \sigma_{n}$ is the elasticity of labor supply $\left(N_{j, t}\right)$ measured as hours worked. Households derive direct value from the liquidity services of real money holdings $\left(\mathcal{M}_{j, t} / P_{t}\right)$, where $\sigma_{m}$ is the interest elasticity of money demand.

Households have access to three types of assets: money $\mathcal{M}_{j, t}$, domestic currency bonds $B_{j, t}$ and foreign currency bonds $B_{j, t}^{*}$. Domestic bonds pay a gross nominal rate of return $I_{t}^{b}$ in domestic currency, whereas foreign bonds pay an exchange rate adjusted, $\varepsilon_{t}$, gross nominal rate of return $I_{t}^{b *}$. While capital mobility is flexible (i.e., no portfolio adjustment costs) domestic households face a risk premium $\mu_{t}^{b *}$ when borrowing in foreign currency. Similarly, the stochastic disturbance term $\mu_{t}^{b}$ represents the domestic risk premium (spread) over the monetary policy rate for domestic currency asset holdings $2^{2}$ The representative household's budget constraint is as follows:

$$
\begin{gathered}
P_{t}^{o} O_{j, t}^{c}+P_{t}^{h} C_{j, t}^{h}+P_{t}^{f} C_{j, t}^{f}+\frac{B_{j, t}}{I_{t}^{b} \mu_{t}^{b}}+\frac{\varepsilon_{t} B_{j, t}^{*}}{I_{t}^{b *} \mu_{t}^{b *}}+\mathcal{M}_{j, t}= \\
B_{j, t-1}+\varepsilon_{t} B_{j, t-1}^{*}+\mathcal{M}_{j, t-1}+W_{t} N_{j, t}+\Pi_{j, t}+T_{j, t},
\end{gathered}
$$

where $W_{t}$ is the nominal wage set by labour unions, $\Pi_{j, t}$ are dividends received from domestic firms, and $T_{j, t}$ represents lump-sum net transfers from government. Given the pricing functions Eq. 5 and Eq. 6 we can re-write the budget constraint as

$$
\begin{array}{r}
P_{t} C_{j, t}+\frac{B_{j, t}}{I_{t}^{b} \mu_{t}^{b}}+\frac{\varepsilon_{t} B_{j, t}^{*}}{I_{t}^{b *} \mu_{t}^{b *}}+\mathcal{M}_{j, t}= \\
B_{j, t-1}+\varepsilon_{t} B_{j, t-1}^{*}+\mathcal{M}_{j, t-1}+W_{t} N_{j, t}+\Pi_{j, t}+T_{j, t},
\end{array}
$$

where

$$
\begin{aligned}
P_{t}^{z} Z_{j, t} & \equiv P_{t}^{h} C_{j, t}^{h}+P_{t}^{f} C_{j, t}^{f}, \\
P_{t} C_{j, t} & \equiv P_{t}^{o} O_{j, t}^{c}+P_{t}^{z} Z_{j, t} .
\end{aligned}
$$

Households optimize their consumption-savings decision by maximizing Eq. 7 subject to Eq. 9. The aggregated first order conditions for domestic and foreign bonds give the standard

\footnotetext{
${ }^{2}$ With the assumption of complete markets (i.e., a complete set of contingent claims), the decision problem is identical for all households. This feature allows for a well-defined steady-state for the small open economy (see, e.g., Schmitt-Grohé and Uribe (2003) and Steinbach et al. (2009)).
} 
Euler equations

$$
\begin{aligned}
1 & =\beta E_{t}\left[\frac{\Lambda_{t+1}}{\Lambda_{t}} \frac{P_{t}}{P_{t+1}} I_{t}^{b} \mu_{t}^{b}\right], \\
1 & =\beta E_{t}\left[\frac{\Lambda_{t+1}}{\Lambda_{t}} \frac{P_{t}}{P_{t+1}} I_{t}^{b *} \frac{\varepsilon_{t+1}}{\varepsilon_{t}} \mu_{t}^{b *}\right],
\end{aligned}
$$

where $\Lambda_{t}$ is the marginal utility of consumption and the LaGrangian multiplier of the budget constraint.

Similar to Medina and Soto $(2005)$ and Steinbach et al. $(2009)$, complete international asset markets implies complete international consumption risk sharing. Eqs. 12 and 13 together give the standard uncovered interest parity (UIP) condition:

$$
\left(1+i_{t}^{b}\right)=\left(1+i_{t}^{b *}\right) \frac{\varepsilon_{t+1}}{\varepsilon_{t}} \Phi_{t}
$$

where $I_{t}^{b}=\left(1+i_{t}^{b}\right), I_{t}^{b *}=\left(1+i_{t}^{b *}\right)$ and $\Phi_{t}=\left(\mu_{t}^{b *} / \mu_{t}^{b}\right)$ is the prevailing stochastic risk premium. A positive shock to $\Phi_{t}$, equivalent to a negative demand shock, raises the return on domestic currency bonds relative to foreign currency bonds and reduces current consumption (Smets and Wouters, 2007; Steinbach et al., 2009).

\subsection{Labour supply decisions and the wage-setting equation}

Monopolistically competitive unions set the optimal wage at the prevailing labour demand equilibrium (see, e.g., Gali et al., 2007). There is a continuum of unions, and each union represents workers of a certain type $\tau$. The labour demand schedule that each household type $\tau$ faces is determined by

$$
N_{t}^{\tau}=\left(\frac{W_{t}^{\tau}}{W_{t}}\right)^{-\xi^{w}} N_{t}
$$

where $\xi^{w}$ is the wage elasticity of substitution across different types of households.

Following Calvo-type price-setting, only a random fraction $\left(1-\theta_{w}\right)$ of unions have the opportunity to reset their wages $\left(\tilde{W}_{t}\right)$ each period. Whereas, those unions that cannot reset their wages simply index to the lagged wage rate (Christiano et al., 2005; Smets and Wouters, 2007) $]^{3}$ Therefore, the aggregate wage index is given by:

$$
W_{t}^{1-\xi^{w}}=\theta_{w}\left(\left(\frac{P_{t-1}}{P_{t-2}}\right)^{\gamma_{w}} W_{t-1}\right)^{1-\xi^{w}}+\left(1-\theta_{w}\right)\left(\tilde{W}_{t}\right)^{1-\xi^{w}}
$$

where $\gamma_{w}$ is the degree of wage indexation. The re-optimizing union's problem is to therefore

\footnotetext{
${ }^{3}$ i.e., when wages cannot be reset: $W_{t}^{\tau}=\Gamma_{t} W_{t-1}$, where $\Gamma_{t}=\Pi_{t-1}^{\gamma_{w}}=\left(P_{t-1} / P_{t-2}\right)^{\gamma_{w}}$.
} 
choose $\tilde{W}_{t}$ to maximize the consumption-weighted wage income:

$$
\max _{\tilde{W}_{t}} E_{t} \sum_{i=0}^{\infty}\left(\theta_{w} \beta\right)^{i}\left[\frac{\Gamma_{t+i} \tilde{W}_{t} N_{t+i}^{\tau}}{P_{t+i} \bar{C}_{t+i}^{\sigma_{c}}}-\frac{\left(N_{t+i}^{\tau}\right)^{1+\sigma_{n}}}{1+\sigma_{n}}\right]
$$

subject to the labour demand schedule Eq. 15.4

The first-order condition for the optimal reset wage $\tilde{W}_{t}$ is:

$$
E_{t} \sum_{i=0}^{\infty}\left(\theta_{w} \beta\right)^{i}\left[\Gamma_{t+i} \frac{\tilde{W}_{t}}{P_{t+i}}\left(\frac{1}{M R S_{t+i}}\right)\right]=E_{t} \sum_{i=0}^{\infty}\left(\theta_{w} \beta\right)^{i}\left[\mu^{w}\left(\frac{\tilde{W}_{t}}{W_{t+i}}\right)^{-\xi^{w} \sigma_{n}}\right]
$$

where $M R S_{t+i}=-\Lambda_{N, t} / \Lambda_{t}=\bar{C}_{t+i}^{\sigma_{c}} N_{t+i}^{\sigma_{n}}$ is the marginal rate of substitution between consumption and leisure for households, and $\mu^{w}=\frac{\xi^{w}}{\xi^{w}-1}$ is the steady-state wage markup. Log-linearizing Eq. 18 and combining it with the log-linearized wage index equation (16) gives the forward-looking nominal wage inflation equation A.8, as in the literature.

\subsection{Investment and capital goods}

The capital goods producing firm chooses a path for investment $\left(V_{t}\right)$ that maximises the present value of its profits:

$$
\max _{K_{t+1}, V_{t}} E_{t} \sum_{i=0}^{\infty} \Lambda_{t, t+i}\left[\frac{R_{t+i}^{k} P_{t+i}^{h} K_{t+i}-P_{t+i}^{V} V_{t+i}}{P_{t+i}^{h}}-\phi\left(\frac{V_{t+i}}{K_{t+i}}\right) K_{t+i}\right],
$$

subject to the capital accumulation equation given by

$$
K_{t+1}=(1-\delta) K_{t}+V_{t}
$$

where $\delta$ measures the depreciation rate of capital, and $K_{t}$ represents the physical capital stock at the beginning of period $t . R_{t}^{k}$ is the gross (real) return on rented capital holdings, and $\phi(\cdot)$ captures the adjustment cost of capital installation $5^{5}$ As in Adolfson et al. (2007), we assume that the prices of domestically produced consumption goods and investment goods coincide $\left(P_{t}^{h}=P_{t}^{V}\right){ }^{6} \Lambda_{t, t+i}$ denotes the stochastic discount factor for real profits, $i$-periods ahead given by

$$
\Lambda_{t, t+i} \equiv \beta^{i}\left(\frac{\bar{C}_{t+i}}{\bar{C}_{t}}\right)^{-\sigma_{c}}
$$

The first order conditions for the capital goods producer problem are:

\footnotetext{
${ }^{4} \bar{C}_{t+i}=\left(C_{t+i}-\phi C_{t-1+i}\right)$.

${ }^{5} \phi^{\prime}>0, \phi^{\prime \prime}<0, \phi^{\prime}(\delta)=0, \phi(\delta)=0$. Specifically, $\phi\left(V_{t} / K_{t}\right) K_{t}=\left(\kappa_{v} / 2 \delta\right)\left(V_{t} / K_{t}-\delta\right)^{2} K_{t}$.

${ }^{6}$ In Adolfson et al. (2007) and Medina and Soto (2007, 2014) there are monopolistically competitive firms in the import and export markets for both investment and consumption goods. When nominal rigidities (as in Smets and Wouters, 2002) are zero, exchange rate pass-through to import and export prices is complete.
} 


$$
\begin{aligned}
Q_{t} & =E_{t}\left\{\Lambda_{t, t+1}\left[R_{t+1}^{k}+Q_{t+1}(1-\delta)+\phi_{t+1}^{v} V_{t+1}-\phi_{t+1}\right]\right\} \\
Q_{t} & =\frac{P_{t}^{V}}{P_{t}^{h}}+\phi_{t}^{v} K_{t},
\end{aligned}
$$

where $\phi_{t}^{v}=\left(\kappa_{v} / \delta\right)\left(V_{t} / K_{t}-\delta\right)\left(1 / K_{t}\right)$ and $Q_{t}$ is the marginal value of an additional unit of capital. That is, $Q_{t}$ is the "shadow value" of the capital accumulation constraint (23) and equals the present discounted value of the marginal profits of an additional unit of capital (22). 7

\subsection{Domestic production}

The domestic goods-producing sector is made up of a continuum of infinitely lived firms indexed by $j \in[0,1]$. Each of these domestic firms combines labour, capital and oil to produce intermediate goods for final good production. Notably, we emphasise the substitutability between capital and oil in the production process (e.g., Kim and Loungani (1992), Rotemberg and Woodford (1996), Backus and Crucini (2000) and Frondel and Schmidt (2002, 2004)) rather than between labour and oil as in Medina and Soto (2005) and Blanchard and Riggi (2013). Capital and oil therefore enter as a CES function within a Cobb-Douglas production function: $Y_{j, t}=A_{t}\left(N_{j, t}\right)^{\alpha}\left[\vartheta\left(K_{j, t}\right)^{1-\nu}+(1-\vartheta)\left(O_{j, t}^{h}\right)^{1-\nu}\right]^{(1-\alpha) /(1-\nu)}$, where $1 / \nu$ captures the elasticity of substitution between physical capital and oil. $A_{t}$ represents the domestic technology shock.

The decision problem can be characterised by two stages. First, firm $j$ minimizes the total cost of production subject to the production constraint. Second, each firm $j$ maximizes its profit function subject to both foreign and domestic demand. Following Calvo (1983), all firms face a probability $\theta_{h}$ of not being able to optimally adjust prices. In this market, final goods producers are monopolistically competitive.

\subsubsection{Demand for inputs and marginal cost}

Each intermediate goods-producing firm $j$ therefore chooses its factor inputs-labour $N_{j, t}$, capital $K_{j, t}$, and oil $O_{j, t}^{h}$ - to minimize the total cost of production, taking prices as given:

$$
\min _{\left\{N_{j, t}, K_{j, t}, O_{j, t}^{h}\right\}} T C_{j, t}+\lambda_{t}\left(Y_{j, t}^{h}-A_{t}\left(N_{j, t}\right)^{\alpha}\left[\vartheta\left(K_{j, t}\right)^{1-\nu}+(1-\vartheta)\left(O_{j, t}^{h}\right)^{1-\nu}\right]^{\frac{1-\alpha}{1-\nu}}\right),
$$

\footnotetext{
${ }^{7}$ In order to ensure $\kappa_{v}$ captures realistic adjustment costs in the investment schedule, we assume that the firm ignores external habit formation of households $(\phi=0)$ in its stochastic discount factor. Preliminary estimations of the model led to either implausibly high estimates (of between 20 and 30) for the capital adjustment cost parameter $\left(\kappa_{v}\right)$ or a fairly sizeable loss of model in-sample fit with $\kappa_{v}$ fixed. One likely reason is due to output, inflation and the interest rate being the only observable variables used for the domestic economy, which restricts including additional shocks (e.g. investment-specific) or the identification of parameters that control for monopolistic competition of investment goods in an open economy (see, e.g., Adolfson et al. (2007) and Medina and Soto (2007, 2014)).
} 
where $T C_{j, t}=\frac{W_{t}}{P_{t}^{h}} N_{j, t}+R_{t}^{k} K_{j, t}+\frac{P_{t}^{o}}{P_{t}^{h}} O_{j, t}^{h}$ is the total real cost of production 8 The first order efficiency conditions for labour, capital, and oil are:

$$
\begin{aligned}
\frac{W_{t}}{P_{t}^{h}} & =\lambda_{t} \frac{\partial Y_{j, t}^{h}}{\partial N_{j, t}}=\alpha \lambda_{t} \frac{Y_{j, t}^{h}}{N_{j, t}} \\
R_{t}^{k} & =\lambda_{t} \frac{\partial Y_{j, t}^{h}}{\partial K_{j, t}}=(1-\alpha) \vartheta \lambda_{t} \frac{Y_{j, t}^{h}}{\left(K_{j, t}\right)^{\nu}\left[\vartheta\left(K_{j, t}\right)^{1-\nu}+(1-\vartheta)\left(O_{j, t}^{h}\right)^{1-\nu}\right]} \\
\frac{P_{t}^{o}}{P_{t}^{h}} & =\lambda_{t} \frac{\partial Y_{j, t}^{h}}{\partial O_{j, t}^{h}}=(1-\alpha)(1-\vartheta) \lambda_{t} \frac{Y_{j, t}^{h}}{\left(O_{j, t}^{h}\right)^{\nu}\left[\vartheta\left(K_{j, t}\right)^{1-\nu}+(1-\vartheta)\left(O_{j, t}^{h}\right)^{1-\nu}\right]},
\end{aligned}
$$

where $\lambda_{t}$ is the real marginal cost of domestic production and the LaGrangian multiplier of the production function.

\subsubsection{Price setting}

Each firm $j$ is monopolistically competitive in its intermediate good $Y_{j, t}^{h}$. The firm is able to brand and sell its good at a markup $P_{t}^{h}$ over marginal cost, taking into account their individual demand curves from domestic and foreign consumers. Here, we assume that both foreign and domestic consumers have identical elasticities with respect to domestic goods. Following Calvo (1983), we assume that only a random fraction $\left(1-\theta_{h}\right)$ of firms can adjust their retail price in each period. Therefore, each firm $j$ faces the following decision problem:

$$
\max _{\left\{\tilde{P}_{t}^{h}\right\}} E_{t} \sum_{i=0}^{\infty} \theta_{h}^{i} \Lambda_{t, t+i}\left[\left(\frac{\Pi_{t+i-1}^{\gamma_{p}} \tilde{P}_{j, t}^{h}}{P_{t+i}^{h}}-\lambda_{t+i}\right) Y_{j, t+i}^{h}\right]
$$

subject to the consumer demand schedule for goods

$$
Y_{j, t+i}^{h}=\left(\frac{\tilde{P}_{j, t}^{h}}{P_{t+i}^{h}}\right)^{-\xi_{t}^{p}} Y_{t+i}^{h}
$$

where $\Lambda_{t, t+i}=\beta^{i}\left(\Lambda_{t+i} / \Lambda_{t}\right)$ is the consumption-based relevant discount factor, and $\xi_{t}^{p}$ is the stochastic price-elasticity of demand for intermediate good $Y_{t}^{h} \unlhd^{9} \tilde{P}_{t}^{h}$ denotes the optimal

\footnotetext{
${ }^{8}$ Notice that while households consider total (headline) price adjustments $\left(\Delta P_{t}\right)$, firms operate in the domestic goods sector only. That is, they consider the price of domestic goods $\left(P_{t}^{h}\right)$ only, and therefore only indirectly internalize oil and foreign price shocks. Therefore, when derivation is complete, the system of equilibrium conditions (specifically the real price of domestic goods in production) must account for the relative price differences conditioned in each sector. In other words, the real price in the domestic economy is in terms of $P_{t}$, and therefore the domestic sector must account for the relative price difference $P_{t}^{h} / P_{t}$.

${ }^{9}$ Note that the above assumption concerning domestic and foreign elasticities implies that $\xi_{t}^{p}$ incorporates both domestic and foreign elasticities of demand with $Y_{t}^{h}=C_{t}^{h}+C_{t}^{*}$, where $C_{t}^{*}$ is foreign consumption of domestic goods. However, as we will see below, the foreign demand for domestic goods in the foreign economy has its own demand curve. As such, it serves as an exogenous foreign demand shock with uncertainty (i.e., foreign demand shocks are not substitutable and have complete pass-through to the real economy).
} 
price set by firms who are able to adjust the price in period $t$, and $\lambda_{t}$ is the real marginal cost of production.

The aggregate price level is determined by

$$
\left(P_{t}^{h}\right)^{1-\xi_{t}^{p}}=\theta_{h}\left(\left(\frac{P_{t-1}^{h}}{P_{t-2}^{h}}\right)^{\gamma_{p}} P_{t-1}^{h}\right)^{1-\xi_{t}^{p}}+\left(1-\theta_{h}\right)\left(\tilde{P}_{t}^{h}\right)^{1-\xi_{t}^{p}},
$$

where $\gamma_{p}$ determines the degree of price indexation for non-optimizing retailers. Solving and linearizing the optimization problem and combining it with Eq. 30 gives the forward-looking New-Keynesian Phillips curve, as in the literature.

\subsection{Domestic importing retailers and incomplete pass-through}

Extensive empirical evidence indicates the tendency for a high degree of pass-through to import prices, whereas the pass-through to domestic prices is more dampened (see Burstein and Gopinath, 2014). For local importing retailers we therefore introduce incomplete passthrough of exchange-rate movements in the short-run (Calvo-type price setting). Specifically, they are import price takers (given the exchange rate) but face a downward sloping domestic demand curve. The law of one price (l.o.p) gap, Eq. 31, therefore measures deviations from the l.o.p. (Monacelli, 2005):

$$
\Psi_{t}^{f} \equiv \frac{\varepsilon_{t} P_{t}^{f *}}{P_{t}^{f}}
$$

where $P_{t}^{f}$ is the price of foreign goods in the domestic currency (or the domestic currency price of imports).

The domestic demand schedule for foreign good $j$ is given by:

$$
C_{j, t}^{f}=\left(\frac{P_{j, t}^{f}}{P_{t}^{f}}\right)^{-\xi^{f}} C_{t}^{f}
$$

where, similar to domestic firms, import firms operate in a Calvo-type sticky price environment. Specifically, prices are adjusted with probability $1-\theta_{f}$ in each period. The aggregate import price index is therefore determined by

$$
\left(P_{t}^{f}\right)^{1-\xi^{f}}=\theta_{f}\left(\left(\frac{P_{t-1}}{P_{t-2}}\right)^{\gamma_{f}} P_{t-1}^{f}\right)^{1-\xi^{f}}+\left(1-\theta_{f}\right)\left(\tilde{P}_{t}^{f}\right)^{1-\xi^{f}}
$$

where $\xi^{f}$ and $\tilde{P}_{t}^{f}$ denote the price-elasticity of demand for foreign goods and the optimal price set by local importing retailers, respectively. If $\Psi_{t}^{f} \equiv 1$ then the l.o.p holds with the foreign price of foreign produced goods (imports) traded with the domestic country $P_{t}^{f *}$, adjusted for the spot nominal exchange rate $\varepsilon_{t}$ (i.e., the price of one unit of foreign currency in terms of the domestic currency). For simplicity, we set $\gamma_{f}$ to zero, which implies that import prices are not indexed to headline inflation. As such, the Calvo price-setting parameter $\theta_{f}$ governs the degree of import price pass-through of foreign goods. 


\subsection{Terms of trade and the real exchange rate}

The foreign demand for domestic goods is captured by the following demand schedule:

$$
C_{t}^{h *}=\gamma_{c}^{*}\left(\frac{P_{t}^{h *}}{P_{t}^{f *}}\right)^{-\xi^{f *}} C_{t}^{*}
$$

where $\xi^{f *}$ is the foreign price elasticity of demand for domestic goods. A higher elasticity implies larger changes in foreign demand for domestic goods given the foreign price of domestic goods relative to foreign goods.

The terms of trade of an economy (excl. oil imports) is defined as the price of imports relative to the price of domestically produced goods:

$$
S_{t}=\frac{P_{t}^{f}}{P_{t}^{h}}
$$

This implicitly assumes that domestic firms cannot price discriminate across markets and that the l.o.p holds for domestic export prices, $\varepsilon_{t} P_{t}^{h *}=P_{t}^{h}$. Medina and Soto (2005) also note that this assumes that the foreign consumption bundle excludes oil and that the share of domestic goods $\gamma_{c}^{*}$ in $C_{t}^{*}$ is negligible.

The definition of the real exchange rate can be written as:

$$
R E R_{t} \equiv \frac{\varepsilon_{t} P_{t}^{f *}}{P_{t}},
$$

which is the price of foreign headline CPI denominated in domestic currency relative to domestic headline CPI. Given that the l.o.p for oil may not hold $\left(\Psi_{t}^{o} \equiv \varepsilon_{t} P_{t}^{o *} / P_{t}^{o}\right)$, we have the following expression for the domestic real price of oil:

$$
\frac{P_{t}^{o}}{P_{t}}=R E R_{t} \frac{P_{t}^{o *}}{P_{t}^{f *}} \frac{1}{\Psi_{t}^{o}}
$$

where $P_{t}^{o *}$ is the foreign currency price of oil in the rest of the world. $P_{t}^{o *} / P_{t}^{f *}$ follows an exogenous stochastic $\mathrm{AR}(1)$ processes. In Section 4.3, Table 6 we compare three alternative model estimates for specifications of the l.o.p gap for oil: $\Psi_{t}^{o} \equiv 1 ; \Psi_{t}^{o}$ is an $\operatorname{AR}(1)$ process; and $\Psi_{t}^{o}$ is endogenous and negatively correlated with $\left(P_{t}^{o *} / P_{t}^{f *}\right)$.

\subsection{International risk sharing and the UIP}

We can combine the definition of the real exchange rate in Eq. 36 with the UIP condition of Eq. 14 to describe the equation of motion for the relative purchasing power parity condition (i.e., the real exchange rate):

$$
E_{t}\left[R E R_{t+1}\right]=R E R_{t} \frac{\left(1+i_{t}^{b}\right)}{\left(1+i_{t}^{b *}\right)} E_{t}\left[\frac{\Pi_{t+1}^{f *}}{\Pi_{t+1}}\right] \frac{1}{\Phi_{t}} .
$$


Note that this condition holds only under complete asset markets (i.e., international risk sharing in consumption (see also, Steinbach et al., 2009, p. 214)). The evolution of the real exchange rate - a measure of trade competitiveness - is rising in the domestic real interest rate $\left(I_{t}^{b} / \Pi_{t+1}\right)$ and falling in the foreign real interest rate $\left(I_{t}^{b *} / \Pi_{t+1}^{f *}\right)$. A positive shock to the prevailing stochastic risk premium $\left(\Phi_{t}\right)$ reduces the real exchange rate of the domestic economy. The domestic short-term nominal interest rate is determined by the following Taylor-type monetary policy reaction function:

$$
I_{t}^{b}=\left(I_{t-1}^{b}\right)^{\rho_{i}}\left(\frac{\Pi_{t}}{\Pi^{\text {target }}}\right)^{\kappa_{\pi}\left(1-\rho_{i}\right)}\left(\frac{Y_{t}}{Y_{t-1}}\right)^{\kappa_{y}\left(1-\rho_{i}\right)} e^{\epsilon_{t}^{i}},
$$

where $\rho_{i}$ captures the degree of interest rate smoothing, $\kappa_{\pi}$ is the weight on inflation, and $\kappa_{y}$ is the weight on output growth. $\epsilon_{t}^{i}$ is the i.i.d monetary policy shock.

\subsection{Aggregate equilibrium and the foreign sector}

In a symmetric equilibrium, all households and firms make identical decisions, so that $C_{j, t}=C_{t}, O_{j, t}^{c}=O_{t}^{c}, B_{j, t}=B_{t}, B_{j, t}^{*}=B_{t}^{*}, Y_{j, t}^{h}=Y_{t}^{h}, N_{j, t}=N_{t}, K_{j, t}=K_{t}, O_{j, t}^{h}=O_{t}^{h}$, $P_{j, t}^{h}=P_{t}^{h}, P_{j, t}^{f}=P_{t}^{f}$ for $\mathrm{j} \in[0,1]$ and $t=0,1,2 \ldots$ Equilibrium in the domestic goods producing sector therefore requires that

$$
\begin{aligned}
P_{t}^{h} Y_{t}^{h} & =P_{t}^{h} C_{t}^{h}+\varepsilon_{t} P_{t}^{h *} C_{t}^{h *} \\
\therefore Y_{t}^{h} & =C_{t}^{h}+C_{t}^{h *} .
\end{aligned}
$$

The total value of exports and imports are given by

$$
\begin{aligned}
\frac{P_{t}^{X}}{P_{t}} X_{t} & =\frac{\varepsilon_{t} P_{t}^{h *}}{P_{t}} C_{t}^{h *} \\
& =\frac{P_{t}^{h}}{P_{t}} C_{t}^{h *} . \\
\frac{P_{t}^{M}}{P_{t}} M_{t} & =\frac{\varepsilon_{t} P_{t}^{f *}}{P_{t}} C_{t}^{f}+\frac{\varepsilon_{t} P_{t}^{o *}}{P_{t}} O_{t} \\
& =R E R_{t} C_{t}^{f}+\frac{\Psi_{t}^{o} P_{t}^{o}}{P_{t}} O_{t},
\end{aligned}
$$

where $O_{t}=O_{t}^{c}+O_{t}^{h}$ is total oil imports used in consumption and production. The aggregate resource constraint then follows as $Y_{t}=C_{t}+V_{t}+X_{t}-M_{t}$.

We deviate from the Medina and Soto (2005) model, where foreign economy dynamics are captured and characterised by exogenous processes, and rather follow Steinbach et al. (2009, pp.216-7) and assume a large open economy for the foreign market. This allows us to specify the foreign rate $I_{t}^{b *}$, foreign inflation $\Pi_{t+1}^{*}=\Pi_{t+1}^{f *}$, and foreign consumption $Y_{t}^{*}=C_{t}^{*}$ according to the standard 3-equation New-Keynesian model, namely: an IS curve, a Phillips curve, and a Taylor-type policy rate rule. Foreign oil price shocks are assumed to not have 
a direct effect on the foreign economy 10

\subsection{Exogenous shocks}

We include 8 exogenous shocks in the model, where each stochastic variable in the linearized model is described as, e.g., $\hat{a}_{t} \equiv \log \left(A_{t}\right)$. The foreign real price of oil follows $\hat{p} \hat{r}_{t}^{o *}=\rho_{o *} \hat{p r}_{t-1}^{o *}+\epsilon_{t}^{o *}$, where the domestic deviations from l.o.p shock, $\hat{\psi}_{t}^{o}$, is assumed to be constant.11 For the domestic economy, the monetary policy shock $\left(\epsilon_{t}^{i}\right)$, as given in Eq. 39 , is i.i.d, whereas the domestic technology shock $\left(\hat{a}_{t}\right)$ and domestic price markup shock $\left(\xi_{t}^{p}\right)$ follow AR(1) processes. Finally, we include a risk premium shock over the policy rate for domestic-currency assets: $\hat{\mu}_{t}^{b}=\rho_{b} \hat{\mu}_{t-1}^{b}+\epsilon_{t}^{b}$. The foreign economy follows with an i.i.d monetary policy shock $\left(\epsilon_{t}^{i *}\right)$ and an $\mathrm{AR}(1)$ process for the foreign supply shock $\left(\hat{a}_{t}^{*}\right)$. In addition, the risk premium shock for foreign-currency assets, equivalent to a foreign demand shock, is $\hat{\mu}_{t}^{b *}=\rho_{b} \hat{\mu}_{t-1}^{b *}+\epsilon_{t}^{b *}$.

\section{Model estimation}

\subsection{Data and calibration}

We estimate the model over the sample period 1995:Q1-2017:Q2. The dataset contains 7 observable variables.12 For the domestic economy, South Africa, we have gross domestic product (GDP) per capita, the total consumer price index, and the 3-month treasury bill rate. The foreign economy macroeconomic data are calculated using a trade-weighted average for the USA, UK, Euro area and Japan.13 Combined, we have the foreign gross domestic product (GDP) per capita, the foreign total consumer price index, and the foreign 3-month treasury bill (government securities) rate. Finally, we include the foreign relative (real) price of oil: international price of Brent oil deflated by the foreign consumer price index. All data are log-differenced except interest rates - which are in quarterly terms.

Table 1 presents the calibrated parameters. Table 2 shows the corresponding implied steady-state values from the model setup. For households, the share of imported goods in the non-fuel (core) consumption basket is set to 0.27, whereas the import share of oil in consumption is 0.07. Both values correspond to the aggregate South African trade statistics and the implied steady-state values from the model (in Table 2). Following the small open economy models of Faia and Monacelli (2008) and Steinbach et al. (2009), we calibrate the external habit formation parameter $\phi$ to be 0.7 and the elasticity of labour supply parameter

\footnotetext{
${ }^{10}$ See Appendix A for the full linearized system of equilibrium conditions.

${ }^{11}$ In Section 4.3 . Table 6 we compare three alternative model estimates for specifications of the l.o.p gap for oil: (1) a constant $\left(\hat{\psi}_{t}^{o} \equiv 0\right) ;(2)$ an exogenous $\operatorname{AR}(1)$ process $\left(\hat{\psi}_{t}^{o}=\rho_{\psi} \hat{\psi}_{t-1}^{o}+\epsilon_{t}^{\psi}\right)$; and (3) an endogenous process negatively correlated with $p r_{t}^{o *}\left(\hat{\psi}_{t}^{o}=\rho_{\psi} \hat{\psi}_{t-1}^{o}-\rho_{\psi *} \hat{p r_{t-1}^{o *}}\right)$. We find that a constant l.o.p gap for oil provides the best interpretable results without loss of generality.

${ }^{12}$ See the appendix for data and sources.

${ }^{13}$ The USA, UK, Euro area and Japan make up $67 \%$ of total trade over the sample period. From 1994 to 2002 the average was 77.65\%; from 2003 to 2009 the average was 70.53\%; from 2010 to 2012 the average was $54.83 \%$. The recent drop is due to China's current $20 \%$ share of trade with South Africa. (SARB Quarterly Bulletin, December 2008 and June 2014).
} 
$\sigma_{n}$ to be 3. Similarly, the discount factor $\beta$ equals 0.99 . For firms, the share of labour in production is 0.7 , whereas the relative share of capital to oil in production is 0.9 (Alba et al., 2013). To ensure a steady-state return on capital of $4 \%$, the rate of physical capital depreciation is set to 0.03. Following Bernanke et al. (1999), we fix the elasticity of the price of capital with respect to the investment-capital ratio $\left(\kappa_{v}\right)$ to 0.25 . We assume wage contracts are reset, on average, every 4 quarters $\left(\theta_{w}=0.75\right)$ with a moderate degree of price indexation $\left(\gamma_{w}=0.5\right)$. A wage elasticity of substitution of 5 implies a steady-state markup of $25 \%\left(\frac{\xi_{w}}{\xi_{w}-1}\right)$. The remaining domestic economy steady-state parameters are calibrated directly from the aggregate data and implied model values.

Table 1: Calibrated parameters

\begin{tabular}{llc}
\hline Parameter & Description & Value \\
\hline Households & & \\
$\gamma_{c}$ & Import share of foreign goods in non-fuel goods consumption & 0.27 \\
$\gamma_{o}$ & Import share of oil in consumption & 0.07 \\
$\beta$ & Discount factor & 0.99 \\
$\phi$ & Habit formation & 0.70 \\
$\sigma_{n}$ & Elasticity of labour supply & 3.00 \\
Firms & & \\
$\alpha$ & Share of labour in firm production & 0.70 \\
$\vartheta$ & Relative share of capital to oil in production & 0.90 \\
$\delta$ & Rate of depreciation & 0.03 \\
$\kappa_{v}$ & Physical capital adjustment costs & 0.25 \\
Unions & & \\
$\theta_{w}$ & Sticky wage adjustment & 0.75 \\
$\gamma_{w}$ & Wage indexation & 0.50 \\
$\xi_{w}$ & Wage elasticity of substitution & 5.00 \\
$F o r e i g n$ & economy & \\
$\phi^{*}$ & Habit formation & 0.00 \\
$\sigma_{n}^{*}$ & Elasticity of labour supply & 3.00 \\
$\gamma_{p}^{*}$ & Price indexation & 0.00 \\
Aggregate & ratios & \\
$V / Y$ & Investment-output & 0.20 \\
$X / Y$ & Export-output & 0.28 \\
$M / Y$ & Import-output & 0.27 \\
$O / M$ & Import share of fuel to total merchandise imports & 0.16 \\
$O^{c} / O$ & Household's consumption share of fuel imports & 0.75 \\
\hline
\end{tabular}

\subsection{Prior and posterior parameters}

Tables 3 and 4 present the prior and posterior statistics for the estimated parameters. For the eight stochastic shocks, we set the prior means of the autoregressive coefficients to 0.75 , each with a standard deviation of 0.1 . The variances of the shocks follow inverse gamma distributions with a prior mean of 0.01 , the exception being the foreign real price of oil shock $\left(\epsilon_{o *}\right)$, which is set to 0.1 (see, e.g., Medina and Soto, 2005).

In line with the literature, we assume the substitutability of oil in household consumption and firm production is low (see, e.g., Backus and Crucini, 2000). The inverse elasticity of 
Table 2: Implied steady-state values from the model

\begin{tabular}{lll}
\hline Parameter & Description & Value \\
\hline $1 / \beta-(1-\delta)$ & Return on capital & 0.040 \\
$\frac{V}{Y} / \delta$ & Capital-output ratio & 6.670 \\
$\left(1-\frac{V}{Y}-\frac{X}{Y}+\frac{M}{Y}\right)$ & Total consumption-output ratio & 0.795 \\
$\left(1-\frac{X}{Y^{h}}\right)$ & Domestic consumption-production ratio & 0.720 \\
$\left(1-\frac{O}{M}\right)$ & Consumption of foreign goods to total imports & 0.840 \\
$\left(1-\frac{O^{c}}{O}\right)$ & Firm's usage share of fuel imports & 0.250 \\
\hline
\end{tabular}

substitution between capital and oil $(\nu)$ is set to 2 with a standard deviation of 0.25 , close to the values of 1.43 and 1.54 given in Kim and Loungani (1992) and Alba et al. (2013). Following Medina and Soto (2005), we set the elasticity of substitution between oil and consumption $\left(\eta_{o}\right)$ to 0.2 with a standard deviation of 0.05 . A foreign demand elasticity $\left(\xi^{f *}\right)$ of 2 falls within the range of estimates (from 1.36 to 4.59) in Adolfson et al. (2007, pp. 500-502). Given this wide range we choose a standard deviation of 0.5 for $\xi^{f *}$. The prior distributions for domestic prices and the monetary policy rule conform closely to other estimates for the South Africa economy and open economy models in general (see, e.g., Adolfson et al., 2007; Steinbach et al., 2009).

The pass-through of import prices into domestic retail prices tends to be low (Monacelli, 2005; Burstein and Gopinath, 2014). Import prices therefore exhibit higher price stickiness, to which we set $\theta_{f}$ a prior mean of 0.8 and standard deviation of 0.05 . As a result, the price adjustment mechanism required to bring real relative prices into equilibrium falls more heavily on the nominal exchange rate. That is, consistent with small open economies, low pass-through is associated with higher exchange rate variability.

For the foreign economy, we restrict the standard 3-equation New-Keynesian model with zero habit formation and no price indexation. Structural persistence in consumption is therefore governed by the foreign risk aversion coefficient $\sigma_{c}^{*}$, to which we set the prior mean to 1 with a standard deviation of 0.2. Similarly, Calvo foreign prices control the degree of price stickiness. The prior mean for $\theta^{*}$ is set to 0.75 with a standard deviation of 0.1 .

The posterior parameter estimates in Tables 3 and 4 are based on standard Bayesian techniques (e.g., Adolfson et al., 2007). Most of the prior distributions are shown to be robust to the data. Notably, domestic households exhibit a relatively higher degree of risk aversion (3.6) and therefore respond more smoothly to interest rates. A difference of 0.36 between the posterior means of $\eta_{c}$ and $\eta_{o}$ implies that households raise their consumption of domestic goods in response to real exchange rate increases (i.e., an improved competitiveness) and reduce their consumption of domestic goods when relative domestic prices increase (see Eq. A.1). The reverse holds for the consumption of foreign goods in Eq. A.2. The data also predicts a foreign demand elasticity close to 0.3 , which is lower than the estimates identified in Adolfson et al. (2007) for the euro area as well as Medina and Soto (2005) for the Chilean economy. In both Adolfson et al. (2007, p.488) and Medina and Soto (2005, p.9-10), however, the foreign economy is identified exogenously by autoregressive processes. In our model, the foreign sector contains endogenous frictions which may reduce the need 
Table 3: Structural parameters

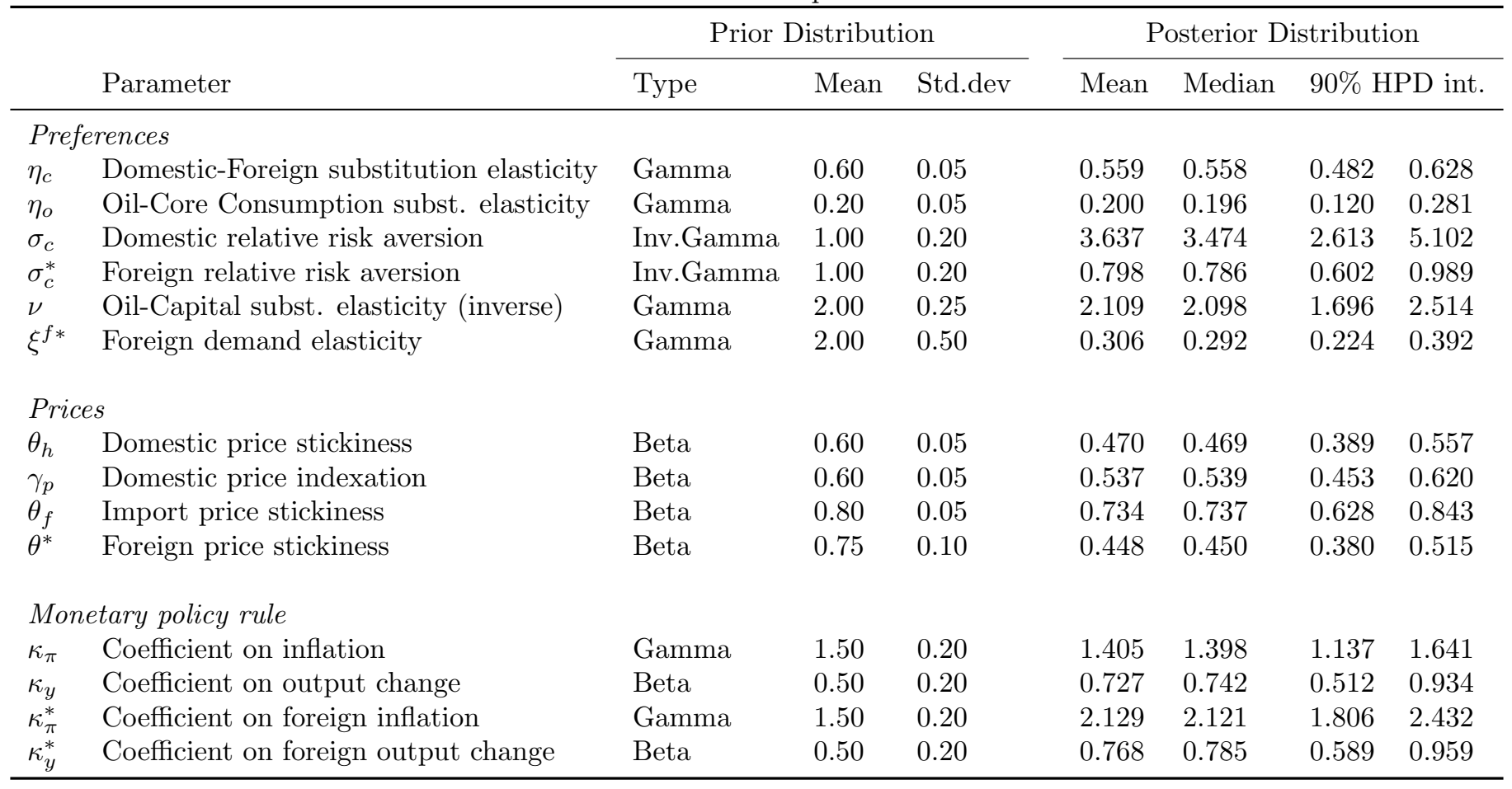

for a high degree of foreign demand elasticity. Import price stickiness remains high (0.73) relative to domestic and foreign Calvo prices (0.47 and 0.45$)$. These results follow closely to that of Steinbach et al. (2009, p.219) for the South African economy. Similarly, we find that the South African monetary authorities have a consistent anti-inflation bias $\left(\kappa_{\pi}>1\right)$ and a relatively large weight on output - indicating greater exploitation of the Phillips curve's output-inflation trade-off (see also, Ortiz and Sturzenegger, 2007, p.667-671). Finally, the autoregressive coefficients for the eight estimated shocks are all persistent with posterior means at 0.7 or higher. The contribution of the various shocks to the model are studied in more detail in the next section.

In order to highlight the role of oil in a small open oil-importing economy, we estimate the model described in Section 2 excluding oil as a factor of production and as a commodity for consumption. The baseline model without oil (no oil hereafter) is obtained by setting the shares of oil in consumption and production to zero $\left(\gamma_{o}=0 ; \vartheta=1\right)$. Table 6 compares the posterior parameter estimates for the no oil model to that of the model with oil (oil hereafter). Section 4.3 discusses these results in more detail ${ }^{14}$

\footnotetext{
${ }^{14}$ Figure $\mathrm{C} .2$ plots the prior and posterior distributions of the estimated parameters. The parameters that exhibit very similar prior and posterior means and distributions are: $\left\{\eta_{c}, \eta_{o}, \nu, \rho_{p}, \epsilon_{p}\right\}$. An identification analysis (following Ratto (2008) and Ratto and Iskrev (2011)) shows that all parameters are identified in the model at the posterior mean. The parameter of most concern (i.e., that shows the weakest identifiable patterns) is $\nu$. Based on collinearity patterns, the identification analysis suggests that adjusting the prior
} 
Table 4: Exogenous processes

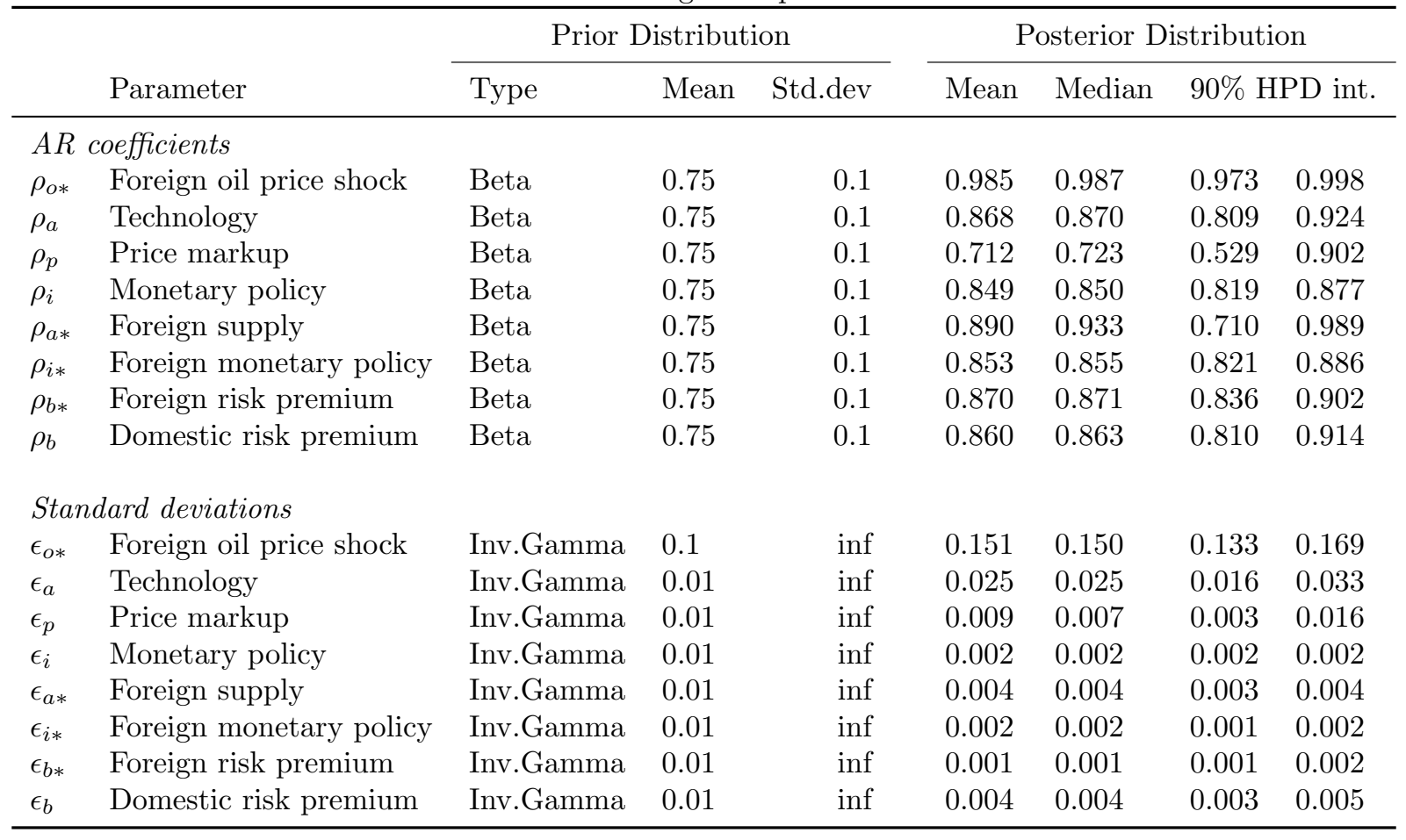

\section{Results}

\subsection{Historical and variance decomposition}

Table 5 reports the variance decompositions for the three main variables of interest: output, total (headline) inflation, and the nominal interest rate. The results are shown for 1-quarter, 1-year, 2-year, and 5-year horizons 15 Columns 2 to 5 report the results for the model with oil (oil hereafter). Columns 6 to 9 report the results for the baseline model without oil (no oil hereafter). Figure 2 shows the results for the historical decompositions of the same three variables over the sample period 1995:Q1-2017:Q2. The purpose of this section is to provide a formal assessment of the contribution of each structural shock to fluctuations in the endogenous variables, firstly, at different horizons, and secondly, at each observation of the actual data. We find that oil price shocks have a significant effect on all three macro variables.

The effect of a foreign real oil price shock $\left(\epsilon_{o *}\right)$ on output is strong and persistent across all horizons (between 9.6\% and 26.7\%). Given the model setup, a decline in the oil price has an

distribution of $\nu$ will likely be offset by changes in $\theta_{f}$ and/or $\eta_{o}$. Table 6 supports this conclusion: excluding oil (no oil model) results in slightly more import price stickiness $\left(\theta_{f}\right)$ and significantly lower domestic-foreign consumption elasticity of substitution $\left(\eta_{c}\right)$. The full set of results on the prior and posterior distributions, the posterior densities, MCMC diagnostics, and identification tests of the corresponding parameters are available on request.

${ }^{15} 1$-4 quarters captures the short-run, 8 quarters the medium-run, and 20 quarters the long-run. 
important direct real effect on domestic production and consumption activities. Traditional supply and demand dynamics intuitively describe the long-run versus short-run effect of domestic demand and supply shocks. In the short-run, the domestic risk premium shock $\left(\epsilon_{b}\right)$ contributes $31.0 \%$ after 1 -quarter and $11.0 \%$ after 1 -year. The impact of this domestic demand shock declines quickly, contributing $7.1 \%$ and $5.4 \%$ in the medium and long-run respectively. In addition, the domestic monetary policy shock shows a similar pattern, but at approximately one-third the magnitude. In contrast, the domestic technology shock contributes $44.9 \%$ in the first quarter to almost two-thirds the variance of output after 5years. Notably, other than the oil price, foreign economy shocks have a negligible impact on the domestic real economy. This result is in line with similar SOE-NKDSGE models estimated for South Africa (e.g., Steinbach et al., 2009, Alpanda et al., 2010) 16 Compared to the no oil model, we find that the technology and risk premium shock are reduced by approximately 20 and 10 percentage points across all horizons, whereas the monetary policy shock increases in the short run by about 5 percentage points.

The contribution of the foreign real oil price shock has a significant impact on total headline inflation across all horizons: from $44.9 \%$ after the first quarter to $30.0 \%$ after 5 years. Compared to the no oil model, the impact of the technology is dampened in the first quarter horizon only, and still contributes half of the forecast error variance of headline inflation. That said, it is clear that the impact of the price markup shock is significantly reduced after introducing the oil cost channel. In contrast to Steinbach et al. (2009) and Alpanda et al. (2010), monetary policy surprises and price markup shocks are the least important domestic shocks in both models; whereas the impact of foreign economy shocks are again negligible ${ }^{17}$

In the no oil model, nominal interest rate is mainly driven by the monetary policy shock in the short-run, and the domestic risk premium and technology shocks in the medium- to long-run (see also, Steinbach et al., 2009, p. 222). Introducing oil significantly reduces the contributions of the price markup shock and the monetary policy shock. A sizeable firstquarter contribution of the foreign real oil price to the variance of the short-term nominal interest rate suggests a strong initial policy response to oil price shocks, which also partly accounts for the strong first-quarter reaction of the monetary authorities in the no oil model ${ }^{18}$ Over the medium- to long-run, the effect of foreign real oil price shocks is smaller but noticeable. In summary, it is clear that oil price shocks are a key driver of output, inflation

16 Alpanda et al. (2010) compare Steinbach et al. $s$ ( (2009) model to a model with an independent country risk premium shock in the UIP condition. For both models, they find that the combined contributions of foreign shocks to inflation, output and nominal interest rate are less than $1 \%$ across all horizons. Adolfson et al. (2007, p. 506) find a similar result in an estimated model for the Euro area.

${ }^{17}$ From Eq. A.22 $\hat{p} \hat{r}_{t}^{o}-\hat{p r}_{t}^{o *}=r \hat{e} r_{t}+\hat{\psi}_{t}^{o}$, we can see that when deviations from the l.o.p for oil are zero $\left(\hat{\psi}_{t}^{o}=0\right)$ the difference between the domestic and foreign real price of oil are fully absorbed by the real exchange rate $\left(r \hat{e} r_{t}\right)$. Given the contribution of l.o.p deviations for oil, the net effect of the foreign oil price shock is not significantly affected (see, e.g., Figure C). A comparison of historical decomposition results from the alternative specifications in Table 6 are available upon request.

${ }^{18}$ This result also provides some impetus for the significant improvement in the first-quarter forecast of the nominal interest rate during (Table 7). 
and interest rates in a small open economy. This is further substantiated by the minimal explanatory power of real and nominal foreign economy shocks in describing the domestic business cycle.
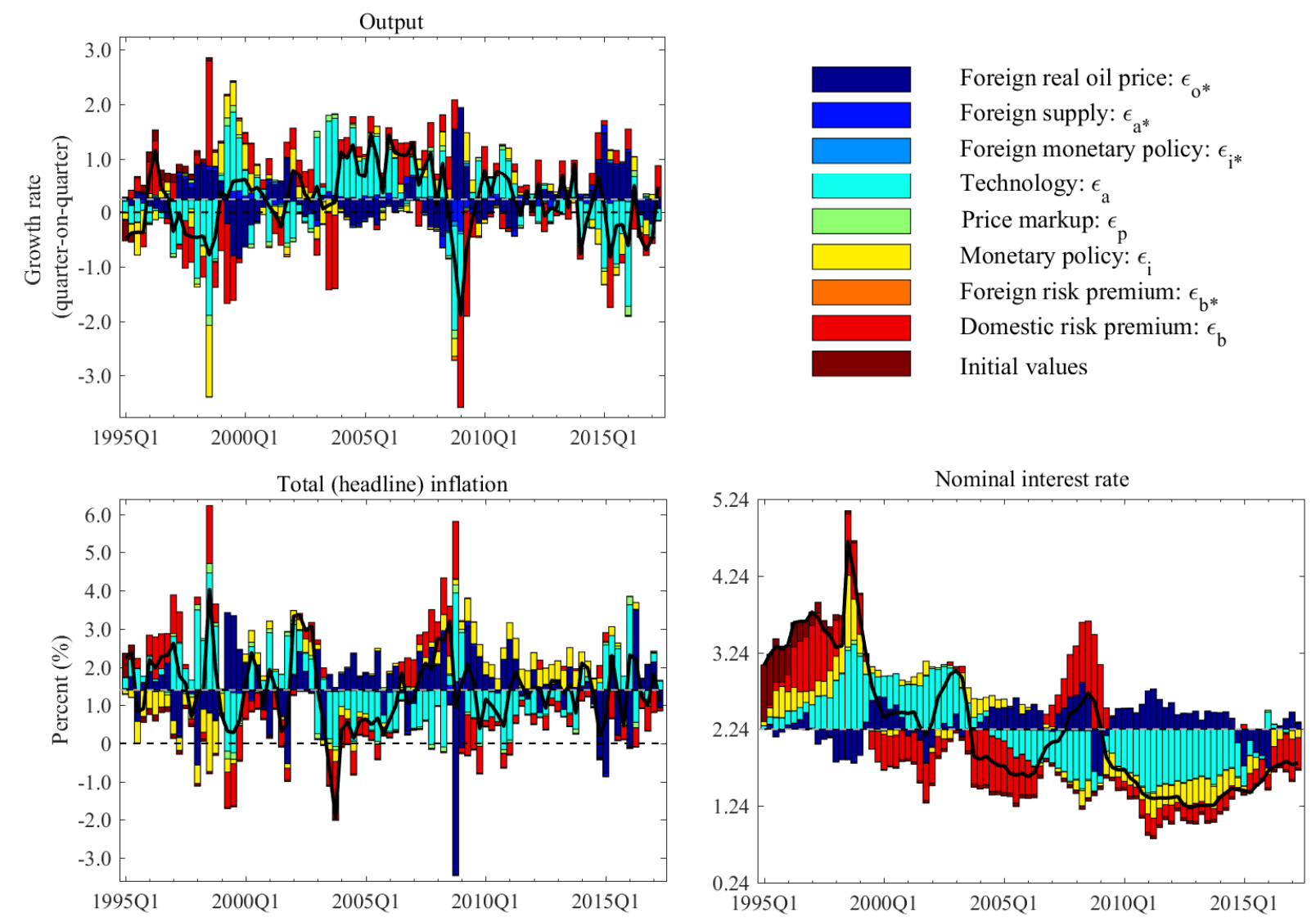

Figure 2: Historical decomposition: Output (top-left); Total inflation (bottom-left); Nominal interest rate (bottom-right)

The historical decompositions of the same three variables over the sample period 1995:Q12017:Q2 are shown in Figure 2. Intuitively, positive oil price shocks should feed through into higher headline inflation and lower output, and vice versa. This effect can be clearly seen over the whole sample period: most notably around the periods of large declines in the foreign real price of oil in 1997/8, 2001, 2008/9 and 2014/15 19 Also, foreign oil price shocks tend to offset technology and risk premium shocks. The recent Great Recession is a case in point, whereby the decline in oil prices dampened the negative impact of technology and risk premium shocks on output and inflation. Turning to the short-term nominal interest rate

\footnotetext{
${ }^{19}$ The largest quarter declines for each episode were: -25\% (1998Q1); -24\% (2001Q4); -52\% (2008Q4); $-29 \%$ (2015Q1).
} 
Table 5: Forecast error variance decomposition of output, total inflation and nominal interest rate

\begin{tabular}{|c|c|c|c|c|c|c|c|c|}
\hline \multicolumn{9}{|c|}{ Variance decomposition of output } \\
\hline & \multicolumn{4}{|c|}{ Oil model: Time Horizons } & \multicolumn{4}{|c|}{ No oil model: Time Horizons } \\
\hline Shocks & 1-quarter & 1-year & 2-years & 5-years & 1-quarter & 1-year & 2-years & 5 -years \\
\hline$\epsilon_{o *}$ & 9.62 & 15.61 & 18.93 & 26.70 & - & - & - & - \\
\hline$\epsilon_{a *}$ & 0.97 & 0.88 & 1.08 & 1.29 & 1.79 & 2.29 & 3.20 & 4.35 \\
\hline$\epsilon_{i *}$ & 0.11 & 0.02 & 0.02 & 0.01 & 0.25 & 0.09 & 0.07 & 0.08 \\
\hline$\epsilon_{a}$ & 44.93 & 66.2 & 68.76 & 63.47 & 22.77 & 48.69 & 59.40 & 63.73 \\
\hline$\epsilon_{p}$ & 4.27 & 3.03 & 2.07 & 1.54 & 13.06 & 12.89 & 9.51 & 7.68 \\
\hline$\epsilon_{i}$ & 9.02 & 3.22 & 2.09 & 1.61 & 16.72 & 9.74 & 7.60 & 6.70 \\
\hline$\epsilon_{b *}$ & 0.1 & 0.02 & 0.01 & 0.01 & 0.23 & 0.08 & 0.07 & 0.07 \\
\hline$\epsilon_{b}$ & 30.98 & 11.01 & 7.05 & 5.36 & 45.17 & 26.23 & 20.15 & 17.39 \\
\hline \multicolumn{9}{|c|}{ Variance decomposition of total inflation } \\
\hline & \multicolumn{4}{|c|}{ Oil model: Time Horizons } & \multicolumn{4}{|c|}{ No oil model: Time Horizons } \\
\hline Shocks & 1-quarter & 1-year & 2-years & 5-years & 1-quarter & 1-year & 2 -years & 5 -years \\
\hline$\epsilon_{o *}$ & 44.92 & 31.11 & 30.18 & 30.00 & - & - & - & - \\
\hline$\epsilon_{a *}$ & 0.09 & 0.10 & 0.10 & 0.12 & 0.17 & 0.16 & 0.18 & 0.23 \\
\hline$\epsilon_{i *}$ & 0.01 & 0.00 & 0.00 & 0.00 & 0.00 & 0.00 & 0.00 & 0.00 \\
\hline$\epsilon_{a}$ & 40.11 & 51.31 & 51.41 & 51.59 & 53.26 & 52.28 & 50.38 & 50.35 \\
\hline$\epsilon_{p}$ & 3.66 & 3.62 & 3.89 & 3.88 & 34.67 & 26.29 & 26.90 & 26.78 \\
\hline$\epsilon_{i}$ & 2.40 & 2.81 & 2.85 & 2.83 & 2.83 & 4.68 & 4.76 & 4.73 \\
\hline$\epsilon_{b *}$ & 0.01 & 0.00 & 0.00 & 0.00 & 0.00 & 0.00 & 0.00 & 0.00 \\
\hline$\epsilon_{b}$ & 8.80 & 11.03 & 11.55 & 11.58 & 9.06 & 16.58 & 17.78 & 17.91 \\
\hline \multicolumn{9}{|c|}{ Variance decomposition of nominal interest rate } \\
\hline & \multicolumn{4}{|c|}{ Oil model: Time Horizons } & \multicolumn{4}{|c|}{ No oil model: Time Horizons } \\
\hline Shocks & 1-quarter & 1-year & 2-years & 5-years & 1-quarter & 1-year & 2-years & 5 -years \\
\hline$\epsilon_{o *}$ & 34.22 & 16.44 & 12.91 & 12.78 & - & - & - & - \\
\hline$\epsilon_{a *}$ & 0.01 & 0.02 & 0.03 & 0.05 & 0.03 & 0.05 & 0.10 & 0.20 \\
\hline$\epsilon_{i *}$ & 0.00 & 0.00 & 0.00 & 0.00 & 0.02 & 0.01 & 0.01 & 0.01 \\
\hline$\epsilon_{a}$ & 17.18 & 37.09 & 35.71 & 34.51 & 16.95 & 32.81 & 30.75 & 29.61 \\
\hline$\epsilon_{p}$ & 1.58 & 2.11 & 1.60 & 1.42 & 10.92 & 12.87 & 9.26 & 8.10 \\
\hline$\epsilon_{i}$ & 21.06 & 7.81 & 5.70 & 5.16 & 52.55 & 18.87 & 13.27 & 11.88 \\
\hline$\epsilon_{b *}$ & 0.00 & 0.00 & 0.00 & 0.00 & 0.02 & 0.01 & 0.01 & 0.01 \\
\hline$\epsilon_{b}$ & 25.94 & 36.53 & 44.04 & 46.08 & 19.52 & 35.39 & 46.61 & 50.20 \\
\hline
\end{tabular}


in the bottom-right of Figure 2, we find a similar relationship between oil price shocks and domestic shocks. Here, oil prices influence interest rates through inflation and real wealth affects on household consumption. Overall, episodes of positive (negative) oil price shocks tend to put upward (downward) pressure on the nominal interest rate, which suggests that oil's effect on inflation is greater than on household consumption. In particular, the $23 \%$ positive real oil price rise in 2008Q2 contributed to inflation concerns and a tighter policy stance going into the Great Recession period, which likely worsening the downturn.

\subsection{Impulse response function analysis: oil versus no oil}

Figures 3(a) and 3(b) show the impulse response function results to a domestic technology shock (column 1), a domestic monetary policy shock (column 2), a domestic price markup shock (column 3), and a foreign real oil price shock (column 4). To highlight the role of oil, we compare the responses of the oil model to that of the no oil model. The no oil model is obtained by setting the shares of oil in consumption and production to zero $\left(\gamma_{o}=0 ; \vartheta=1\right)$. In the Appendix of the paper, we present the impulse responses for the various shocks for the model with and without oil along with the confidence bands, which in turn, highlights the significance, in general, of the effects of the various shocks.

A positive $15 \%$ shock to the foreign real price of oil raises oil inflation in the domestic economy by 14 percentage points (pp) (row 4, column 4 in Figure 3(a)). Total inflation rises $1 \mathrm{pp}$ which implies a pass-through of $7 \%$, wherein the second-round effect on domestic inflation accounts for one-fifth of total inflation. The higher real price of oil therefore induces households to reduce their consumption of both oil (by 2.5\%) and domestic goods. Similarly, the demand for oil in domestic production declines $6.7 \%$ in response to the oil price shock. In aggregate, domestic oil usage falls $4 \%$ (row 4 in Figure 3(b)). Given that foreign goods and physical capital are imperfect substitutes for oil, domestic output declines from the first quarter to its peak in the fourth quarter an accumulated $2.32 \%$. In response to declining output and rising inflation, the monetary authorities raise the short-term nominal interest rate 68 basis points (annualized). Oil price shocks therefore generate a trade-off between output and inflation stabilization when the substitutability of oil in consumption and production is low (Montoro, 2012; Natal, 2012). In our estimated model of the South African economy, the endogenous tightening of monetary policy slows the recovery of the real economy. Compared to the estimated model of Medina and Soto (2005) for the Chilean economy, the responses of inflation, output and the real exchange rate are closely comparable. 20 Although the responses of the policy rate are qualitatively similar, including a risk premium on domestic-currency assets $\left(\mu_{t}^{b}\right)$ in our model reduces the emphasis on endogenous tightening of monetary policy (see Table 5).

Under the monetary policy shock (column 2), the difference between the oil model and no oil model is small. A $0.5 \mathrm{pp}$ (annualized) rise in the policy rate reduces output and total inflation by $0.37 \%$ and $0.22 \mathrm{pp}$, compared to $0.33 \%$ and $0.12 \mathrm{pp}$ in the no oil model.

\footnotetext{
${ }^{20}$ Just like South Africa, Chile too is a small open economy with an inflation targeting monetary policy and a floating exchange rate regime. Both country's are also net importers of oil.
} 

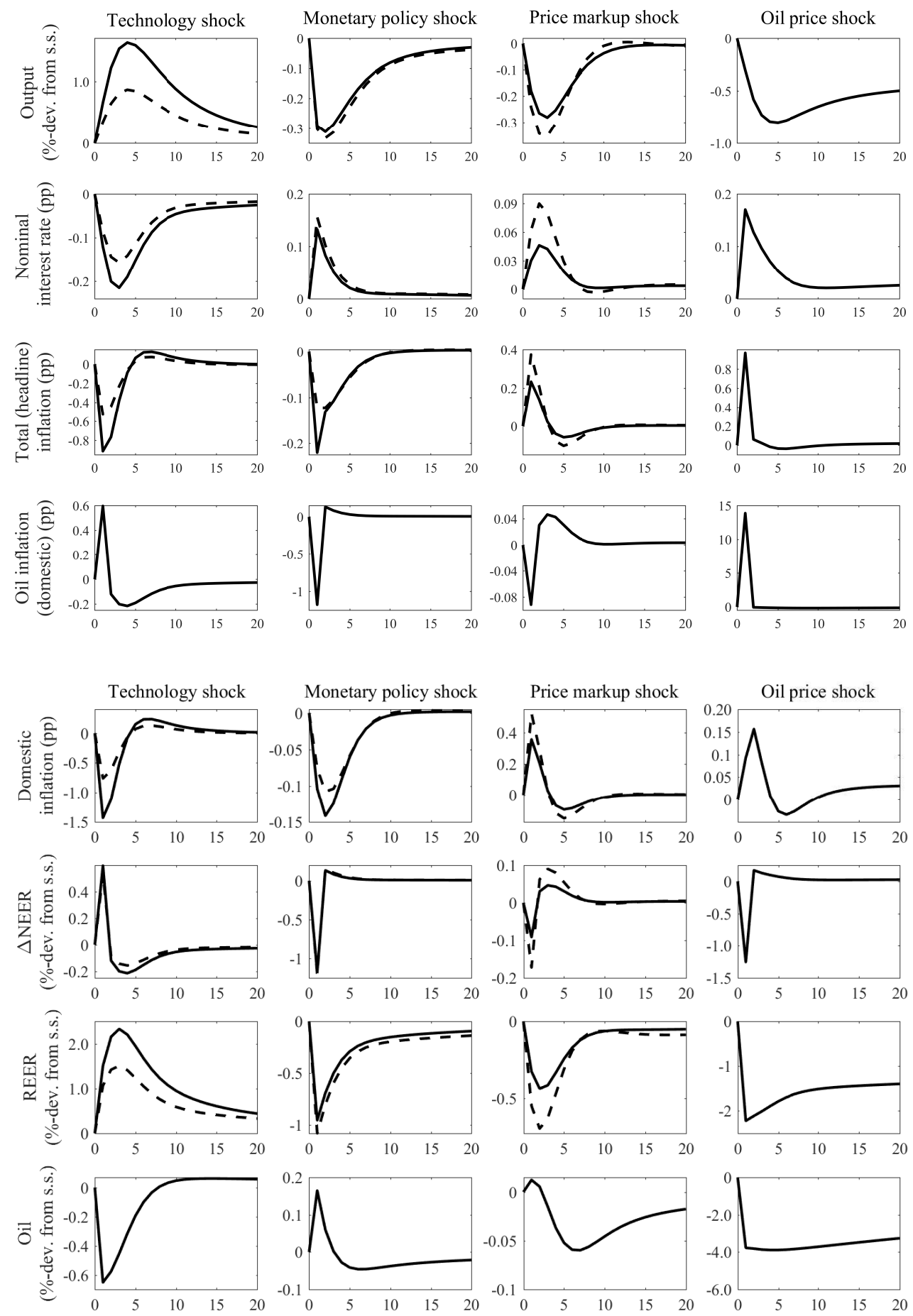

Figure 3: Impulse responses (solid line: oil model; dashed line: no oil model). Figure 3(a) top panel. Figure $3(\mathrm{~b})$ bottom panel. Inflation and interest rates are measured in percentage points. All other variables are measured as \%-deviations from steady-state. 
Conversely, the model with oil significantly reduces the effect of a domestic price markup shock (column 3) and increases the effect of a domestic technology shock (column 1), confirming the variance decomposition results in Table 5. Comparing columns 3 and 4 in Figures 3(a) and 3(b) show that both the domestic price markup shock and the oil price shock have qualitatively analogous impacts on nominal and real variables in the domestic economy. As a result, including oil in the model framework highlights the relative importance of oil price shocks in distorting relative prices. It also clearly explains the dampened effect of price markup shocks in the oil model.

A positive technology shock (column 1) raises output by $0.84 \%$ and reduces domestic inflation by $0.51 \mathrm{pp}$ in the no oil model. In response, the policy rate is cut $0.60 \mathrm{pp}$ (annualized). The oil model introduces imperfect substitutability with capital goods for production and domestic goods for consumption. Due to the tendency of the real oil price to rise and fall with the business cycle (Figure 1), domestic technology shocks are underestimated when oil is excluded from the model ${ }^{21}$ That is, imperfect substitution implies that output is more persistent in response to total factor productivity (technology) shocks. Specifically, in response to improved competitiveness $(R E E R)$ and lower oil imports, exports rise and imports fall which improves the trade balance and therefore total output (see Eqs. A.36 and A.37). Initially, the domestic real price of oil $\left(\hat{p r}_{t}^{o}\right)$ rises in response to higher household consumption and firm production, dampening downward pressure on total inflation from the domestic economy (see Eq. A.17). As a result, the magnitude of the monetary policy response, although larger than that of the no oil model, is dampened by the endogenous presence of oil.

For the open economy variables in Figure 3(b), the competitiveness of the home country improves through a rise (depreciation) in the real effective exchange rate $(R E E R)$. For example, a positive technology shock that reduces unit costs of production leads to domestic goods being relatively cheaper than foreign goods. As a result, the real exchange rate depreciates. In the model economy, international risk sharing in consumption implies that rising domestic consumption relative to foreign consumption must be accompanied by a rising real exchange rate (see Eq. A.5). As such, the results confirm strong co-movement between the real exchange rate and domestic output (e.g., Steinbach et al., 2009). We can also think of nominal effective exchange rate changes $(\triangle N E E R)$ as the price adjustment mechanism that maintains equilibrium between foreign and domestic goods markets; in relative purchasing power parity (PPP) terms, a change in the real effective exchange rate must equate with changes in NEER plus the foreign-domestic inflation differential (Eq. A.23): $\triangle R E E R=$ $\triangle N E E R+\left(\pi^{*}-\pi\right)$. Row 2 shows the well-known phenomenon of nominal exchange rate overshooting, in that initial changes in $N E E R$ tend to be greater than foreign-domestic inflation differentials before returning to relative PPP with $\triangle R E E R \approx 0$. Specifically, arbitrage in international asset markets requires that the uncovered interest parity (UIP) condition holds (Eq. 14), after which the goods market takes time to clear. Corresponding to an extensive literature, in all four shocks we see strong initial co-movement between real

${ }^{21}$ The real oil price has a correlation coefficient with real GDP of 0.37 for growth rates and 0.82 for levels. 
and nominal exchange rates (e.g., Finn, 1999, Burstein and Gopinath, 2014). The foreign oil price shock mimics that of a domestic price markup shock: a rise in headline inflation relative to the foreign economy leads to an appreciation in the real exchange rate. Similarly, a rise in the nominal interest rate relative to the foreign interest rate induces an initial appreciation in $\triangle N E E R$ due to capital inflows. Subsequently, this leads to an expected depreciation in the nominal exchange rate, which satisfies the UIP condition.

Given the impulse response results, it is clear that the model with oil is robust to the baseline small open economy model, and that oil in production and consumption are both important determinants of nominal and real variables in the South African economy.

Table 6: Alternative model parameter estimates

\begin{tabular}{|c|c|c|c|c|c|c|c|c|c|}
\hline & \multicolumn{4}{|c|}{ Posterior Distribution Means } & & \multicolumn{4}{|c|}{ Posterior Distribution Means } \\
\hline & $\begin{array}{l}\text { Baseline } \\
\text { (No oil) }\end{array}$ & $\begin{array}{c}\text { mod.1 } \\
(O i l)\end{array}$ & $\bmod .2$ & $\bmod .3$ & & $\begin{array}{l}\text { Baseline } \\
\text { (No oil) }\end{array}$ & $\begin{array}{l}\text { mod.1 } \\
(\text { Oil })\end{array}$ & $\bmod .2$ & $\bmod .3$ \\
\hline \multicolumn{10}{|l|}{$\begin{array}{l}\text { Marginal } \\
\text { density }\end{array}$} \\
\hline \multicolumn{5}{|c|}{ Structural parameters } & \multicolumn{5}{|c|}{ Shock parameters } \\
\hline$\eta_{c}$ & 0.210 & 0.559 & 0.553 & 0.580 & $\rho_{O *}$ & - & 0.985 & 0.983 & 0.973 \\
\hline$\eta_{o}$ & - & 0.200 & 0.194 & 0.215 & $\rho_{\psi}$ & - & - & 0.483 & 0.852 \\
\hline$\sigma_{c}$ & 3.915 & 3.637 & 3.881 & 3.414 & $\rho_{\psi *}$ & - & - & 0.057 & - \\
\hline$\sigma_{c}^{*}$ & 0.781 & 0.798 & 0.800 & 0.804 & $\rho_{a}$ & 0.862 & 0.868 & 0.869 & 0.894 \\
\hline$\nu$ & - & 2.109 & 2.146 & 1.953 & $\rho_{p}$ & 0.628 & 0.712 & 0.685 & 0.754 \\
\hline \multirow[t]{2}{*}{$\xi_{f *}$} & 0.335 & 0.306 & 0.301 & 0.387 & $\rho_{i}$ & 0.847 & 0.849 & 0.850 & 0.848 \\
\hline & & & & & $\rho_{a *}$ & 0.858 & 0.890 & 0.843 & 0.913 \\
\hline$\theta_{h}$ & 0.498 & 0.470 & 0.466 & 0.629 & $\rho_{i *}$ & 0.836 & 0.853 & 0.853 & 0.854 \\
\hline$\gamma_{p}$ & 0.549 & 0.537 & 0.535 & 0.596 & $\rho_{b *}$ & 0.862 & 0.870 & 0.869 & 0.869 \\
\hline$\theta_{f}$ & 0.759 & 0.734 & 0.735 & 0.762 & $\rho_{b}$ & 0.867 & 0.860 & 0.863 & 0.862 \\
\hline \multirow[t]{2}{*}{$\theta^{*}$} & 0.453 & 0.448 & 0.448 & 0.449 & & & & & \\
\hline & & & & & $\epsilon_{o *}$ & - & 0.151 & 0.151 & 0.151 \\
\hline$\kappa_{\pi}$ & 1.472 & 1.405 & 1.400 & 1.545 & $\epsilon_{\psi}$ & - & - & - & 0.123 \\
\hline$\kappa_{y}$ & 0.608 & 0.727 & 0.716 & 0.796 & $\epsilon_{a}$ & 0.014 & 0.025 & 0.024 & 0.014 \\
\hline$\kappa_{\pi}^{*}$ & 1.739 & 2.129 & 2.114 & 2.125 & $\epsilon_{p}$ & 0.015 & 0.009 & 0.010 & 0.006 \\
\hline \multirow[t]{5}{*}{$\kappa_{y}^{*}$} & 0.623 & 0.768 & 0.758 & 0.751 & $\epsilon_{i}$ & 0.002 & 0.002 & 0.002 & 0.002 \\
\hline & & & & & $\epsilon_{a *}$ & 0.004 & 0.004 & 0.004 & 0.004 \\
\hline & & & & & $\epsilon_{i *}$ & 0.002 & 0.002 & 0.002 & 0.002 \\
\hline & & & & & $\epsilon_{b *}$ & 0.001 & 0.001 & 0.001 & 0.001 \\
\hline & & & & & $\epsilon_{b}$ & 0.003 & 0.004 & 0.004 & 0.003 \\
\hline
\end{tabular}

Note: We exclude parameter descriptions, prior means and standard deviations (see Tables 3 and 4 , and statistic confidence intervals in the table due to the limited space. Section 2.9 provides details of the alternative specifications for $\hat{\psi}_{t}^{o}$. Model $2(\bmod .2)$ is the model with an endogenous l.o.p gap. Model 3 (mod.3) gives the estimates for the model with both the foreign real oil price shock and the deviations from l.o.p for oil shock. 


\subsection{Comparing the fits of the DSGE model with and without oil}

In this subsection, we compare both the in-sample and out-of-sample performances of the DSGE model with and without oil. To assess in-sample fit, as well as robustness, Table 6 compares the posterior parameter estimates for the no oil model to that of the oil models (see Section 2.6 for details of the three specifications corresponding to oil models 1 to 3).22 Notably, the change in parameter values for $\eta_{c}$ and $\sigma_{c}$ seem to be key for the structural dynamics of the oil model: while the majority of structural parameters are robust to the alternative model estimations, excluding oil from the model reduces $\eta_{c}$, the intratemporal elasticity of substitution between domestic goods and foreign goods, from 0.56 to 0.21 , and raises the risk aversion coeffcient $\sigma_{c}$ from 3.64 to 3.92. As a result, the effect of relative price movements on the consumption of foreign and domestic goods is dampened, as well as the response of aggregate consumption to the real interest rate. Both the intra-temporal and inter-temporal consumption $\left(1 / \sigma_{c}\right)$ decisions of households are therefore more muted in the no oil model.

Next we turn our attention to a more robust comparison between the models by looking at one- to eight-quarter-ahead out of sample forecasts for output, inflation and interest rate. For our purpose, we use an out-of-sample period of 2008:Q2 to 2017:Q2 and 2008:Q2 to 2011:Q2 over which the DSGE model is estimated recursively to produce the forecasts at various horizons. The choice of the out-of-sample periods correspond to the start in the recent decline of oil prices and also when the South African economy was on the verge of its largest post-1994 recession. The shorter out-of-sample period focuses on the recession and initial recovery only. Table 7 presents the ratio of root mean square errors (RMSEs) from the model with oil ( oil) relative to the same model without oil (no oil). Understandably, if the ratio is less than one, the model with oil outperforms the model without it. As can be seen from the Table, the oil model outperforms the no oil model for output at horizons one to three. The same holds for horizon three for inflation, whereas, for the interest rate, the model with oil does not outperform the DSGE model without it at any horizons. When we look at the shorter out-of-sample period, the model with oil continues to outperform the model without it for inflation at the third-quarter-ahead forecast, and now for the interest rate at onequarter-ahead. For output, the oil model now outperforms the one without it consistently over horizons one to six. Based on McCkrakens (2007) MSE-F statistic suitable for nested models, we find that the forecasts for output from the oil model are significantly better than those from the no oil version at least at the five percent level of significance for horizons 1 and 2 for output and at horizon 3 for inflation under the longer out-of-sample period.

\footnotetext{
${ }^{22}$ We find that all three specifications for oil provide very similar posterior results and impulse response functions (Figure C). Importantly, mod.1 $\left(\Psi_{t}^{o} \equiv 1\right)$ provides the best interpretable results for the variance and historical decompositions, which comes at the expense of some reduction in in-sample fit compared to adding $\Psi_{t}^{o}$ as an additional exogenous shock (2182.4 versus 2201.1). That is, following the approach of Medina and Soto (2005) does improve the in-sample model fit, but misspecification of the net effect of foreign oil price shocks on the domestic economy remains small (see also Rondina (2017) on irrelevance of oil price endogeneity in structural models). The oil mod.1 specification we adopt follows Sánchez (2011), Natal (2012), and Vásconez et al. (2015).
} 
Table 7: Relative Root Mean Square Errors (RMSEs)

\begin{tabular}{llllllllll}
\hline Horizon & 1 & 2 & 3 & 4 & 5 & 6 & 7 & 8 & Avg. \\
\hline $\begin{array}{l}\text { 2008:Q2-2017:Q2 } \\
\text { Output }\end{array}$ & $0.918^{* *}$ & $0.909^{* * *}$ & 0.995 & 1.016 & 1.000 & 1.017 & 1.035 & 1.016 & 0.988 \\
$\begin{array}{l}\text { Total (Headline) } \\
\text { Inflation }\end{array}$ & 3.172 & 1.059 & $0.938^{* *}$ & 1.045 & 1.001 & 1.043 & 1.089 & 1.041 & 1.299 \\
$\begin{array}{l}\text { Nominal Interest } \\
\text { Rate }\end{array}$ & 1.003 & 1.107 & 1.093 & 1.047 & 1.029 & 1.036 & 1.051 & 1.066 & 1.054 \\
\hline $\begin{array}{l}\text { 2008:Q2-2011:Q2 } \\
\text { Output }\end{array}$ & $0.859^{* *}$ & $0.747^{* * *}$ & $0.920^{*}$ & 0.965 & 0.965 & 0.984 & 1.060 & 1.034 & 0.942 \\
$\begin{array}{l}\text { Total (Headline) } \\
\text { Inflation }\end{array}$ & 3.232 & 1.105 & $0.916^{*}$ & 1.033 & 1.025 & 1.107 & 1.126 & 1.098 & 1.330 \\
$\begin{array}{l}\text { Nominal Interest } \\
\text { Rate }\end{array}$ & $0.762^{* * *}$ & 1.128 & 1.148 & 1.050 & 1.007 & 1.007 & 1.034 & 1.050 & 1.023 \\
\hline
\end{tabular}

Notes: A RMSE ratio $<1$ means that the oil model outperforms the no oil model.

$* * *, * *$, and $*$ indicate significance at the $1 \%, 5 \%$ and $10 \%$ levels.

While, in case of the shorter out-of-sample period, significance is observed for horizons 1 to 3 for output, 3 for inflation and 1 for the interest rate. The fact that introducing a role for oil does not appear to improve inflation (and interest rate) forecasts can be explained by South Africa's relatively successful inflation targeting performance, especially since 2000 (see, e.g., Ortiz and Sturzenegger, 2007).23 More broadly, this echoes Blanchard and Galí (2010) and Blanchard and Riggi (2013) who find that "better monetary policy" since 2000 (in the U.S. and for other advanced economies) has played an important role in dampening the pass-through of oil price movements to inflation. What the results for the recession and recovery period in Table 7 do suggest is a strong one-step-ahead interest rate response during episodes of large oil price fluctuations: in fact, the $23 \%$ increase in the real price of oil in 2008Q2 preceded a 50 basis points increase in the short-term nominal interest rate to its peak (11.3\%) in 2008Q3. At the same time, total headline inflation rose 1.2 percentage points to its peak of $11.2 \%$ before the economy headed into its 2009 recession.

\section{Concluding remarks}

Just like most economies around the world, there is also a huge literature on the role of oil prices in affecting the macroeconomy (and financial market) of South Africa - an oil

\footnotetext{
${ }^{23}$ Ortiz and Sturzenegger (2007, pp. 667-672) find, in comparison to emerging and advanced economies, a consistently strong anti-inflation bias and a stable monetary policy reaction function for the South African Reserve Bank from 1984Q4 to 2006Q4. South Africa explicitly adopted an inflation targeting regime in February 2000.
} 
importing and inflation targeting country. While, these studies generally conclude that the impact of positive oil shocks is inflationary for the South African economy, the evidence is mixed for output, interest rates and exchange rates. This we believe is possibly due to the fact that the South African literature on the effects of oil price is based on atheoretical models and hence, is not robust to choice of variables, models and sample sizes. Given this, in this study, we aim to develop a SOE-NKDSGE model to provide definitive answers to the impacts of oil shocks on the macroeconomic variables of South Africa as obtained from the theoretical framework.

Upon estimating the SOE-NKDSGE model using quarterly data over the period of 1995:Q1 to 2017:Q2, we can draw the following conclusions. Foreign real oil price shocks have a strong and persistent effect on domestic production and consumption activities and, hence, are a fundamental driver of output, inflation and interest rates in both the short- and long-run. Oil price shocks also generate a trade-off between output and inflation stabilisation. As a result, episodes of endogenous tightening of monetary policy slow the recovery of South Africa's real economy.24 Accounting for oil (energy) demand in firm production and household consumption is therefore crucial for policymakers in oil-importing small open economies. In fact, the historical decomposition results show a clear pattern for oil price shocks on output and inflation, most notably around the periods of large declines in the foreign real price of oil in 1998Q1, 2001Q4, 2008Q4 and 2015Q1: lower (higher) oil prices feed through into lower (higher) headline inflation and improved (deteriorated) output conditions. For example, declining oil prices in the recent 2008/9 recession benefited the economy by offsetting adverse demand (risk premium) and supply (technology) shocks. As a result, oil prices influence interest rates through inflation, real wealth effects on household consumption and production capacity. Overall, episodes of positive (negative) oil price shocks tend to put upward (downward) pressure on the nominal interest rate. We also find that the SOE-NKDSGE model with oil significantly improves the out-of-sample forecast for output over the period 2008:Q2-2017:Q2, i.e., during and after the recession that followed the 2008 global financial crisis.

As Kilian (2009) points out, not all oil price fluctuations have the same macroeconomic impacts. For instance, if oil demand and oil prices rise because of strong foreign aggregate demand, worldwide activity expands rather than contracts - as in the case of price increases resulting from foreign oil supply disruptions. Given this, the international dimension of oil trade matters, and the structure of the oil market in DSGE models must be rich enough to identify different kinds of oil demand and supply shocks. While some attempt have been made to enrich the oil-based DSGE models for the US economy (see for example, Peersman and Stevens, 2010; Bodenstein and Guerrieri, 2011), it would be interesting to incorporate such a structure of the oil market in a small open economy model for South Africa as part of future research.

\footnotetext{
${ }^{24}$ In particular, the $23 \%$ positive real oil price rise in $2008 \mathrm{Q} 2$ contributed to inflation concerns and a tighter policy stance going into the Great Recession period, which likely worsening the downturn. Negative oil price shocks, on the other hand, will tend to lead to an accommodative monetary policy response, a widening output gap and likely excessive asset price imbalances.
} 


\section{References}

Adolfson, M., Laséen, S., Lindé, J., Villani, M., 2007. Bayesian estimation of an open economy DSGE model with incomplete pass-through. Journal of International Economics 72, $481-511$.

Ajmi, A., Gupta, R., Babalos, V., Hefer, R., 2015. Oil price and consumer price nexus in South Africa revisited: A novel asymmetric causality approach. Energy, Exploration and Exploitation 33 (1), 63-74.

Alba, J. D., Chia, W.-M., Su, Z., 2013. Oil shocks and monetary policy rules in emerging economies. Applied Economics 45 (35), 4971-4984.

Alpanda, S., Kotzé, K., Woglom, G., 2010. The role of the exchange rate in a New Keynesian DSGE model for the South African economy. South African Journal of Economics 78 (2), 170-191.

An, S., Kang, H., 2011. Oil shocks in a dsge model for the korean economy. Commodity Prices and Markets, East Asia Seminar on Economics 20, 295-321.

Aye, G., Dadam, V., Gupta, R., Mamba, B., 2014. Oil price uncertainty and manufacturing production. Energy Economics 43, 41-47.

Aye, G., Gadinabokao, O., Gupta, R., 2017. Does the South African Reserve Bank (SARB) respond to oil price movements? historical evidence from the frequency domain. Energy Sources 12 (1), 40-46.

Backus, D. K., Crucini, M. J., 2000. Oil prices and the terms of trade. Journal of International Economics 50, 185-213.

Balcilar, M., Uwilingiye, J., Gupta, R., 2018. Dynamic relationship between oil price and inflation in South Africa. Journal of Developing Areas 52 (2), 73-95.

Balcilar, M., van Eyden, R., Uwilingiye, J., Gupta, R., 2017. The impact of oil price on South African gdp growth: A Bayesian Markov Switching-VAR analysis. African Development Review 29 (2), 319-336.

Baumeister, C., Peersman, G., Van Robays, I., 2010. The economic consequences of oil shocks: Differences across countries and time. In: Fry, R., Jones, C., Kent, C. (Eds.), Inflation in an Era of Relative Price Shocks. Reserve Bank of Austrialia, Sydney, pp. $91-128$.

Beidas-Strom, S., Poghosyan, T., February 2011. An estimated dynamic stochastic general equilibrium model of the jordanian economy. IMF Working Paper No. WP/11/28.

Bellamy, D., 2006. The macroeconomic effects of the crude oil price on the South African economy. Unpublished Masters Dissertation. University of Cape Town. 
Bernanke, B., Gertler, M., Gilchrist, S., 1999. The financial accelerator in a quantitative business cycle framework. In: Taylor, J. B., Woodford, M. (Eds.), Handbook of Macroeconomics, 1st Edition. Vol. 1. Elsevier Science B.V., Amsterdam, Ch. 21, pp. 1341-1393.

Blanchard, O. J., Galí, J., 2010. The Macroeconomic Effects of Oil Price Shocks: Why are the 2000s so different from the 1970s? University of Chicago Press, pp. 373-421.

Blanchard, O. J., Riggi, M., October 2013. Why are the 2000s so different from the 1970s? a structural interpretation of changes in the macroeconomic effects of oil prices. Journal of the European Economic Association 11 (5), 1032-1052.

Bodenstein, M., Guerrieri, L., 2011. Oil effciency, demand, and prices: A tale of ups and downs. Board of Governors of the Federal Reserve System, International Finance Discussion Papers, Number 1031.

Burstein, A., Gopinath, G., 2014. International prices and exchange rates. In: Gopinath, G., Helpman, E., Rogoff, K. (Eds.), Handbook of International Economics. Vol. 4. Elsevier B.V., Ch. 7.

Calvo, G., 1983. Staggered prices in a utility-maximizing framework. Journal of Monetary Economy 12 (3), 383-398.

Chisadza, C., Dlamini, J., Gupta, R., Modise, M., 2016. The impact of oil shocks on the South African economy. Energy Sources 11 (8), 739-745.

Christiano, L. J., Eichenbaum, M., Evans, C. L., 2005. Nominal rigidities and the dynamic effects of a shock to monetary policy. Journal of Political Economy 113 (1), 1-45.

Cologni, A., Manera, M., 2008. Oil prices, inflation and interest rates in a structural cointegrated VAR model for the G-7 countries. Energy Economics 30 (3), 856-888.

Cologni, A., Manera, M., 2009. The asymmetric effects of oil shocks on output growth: A Markov-Switching analysis for the G-7 countries. Economic Modelling 26 (1), 1-29.

Cunado, J., Perez de Gracia, F., 2003. Do oil price shocks matter? evidence for some european countries. Energy Economics 25 (2), 137-154.

Cunado, J., Perez de Gracia, F., 2005. Oil prices, economic activity and inflation: Evidence for some Asian countries. The Quarterly Review of Economics and Finance 45 (1), 65-83.

Dagut, M. B., 1978. The economic effect of the oil crisis on south africa. South African Journal of Economics 46 (1), 23-35.

de Bruyn, R., Gupta, R., van Eyden, R., 2015. Can we beat the random-walk model for the South African Rand-U.S. Dollar and South African Rand-UK Pound exchange rates? evidence from dynamic model averaging. Emerging Markets Finance and Trade, Special Issue: Emerging Economies: Business Cycles, Growth, and Policy 51 (3), 502-524. 
Faia, E., Monacelli, T., June 2008. Optimal monetary policy in a small open economy with home bias. Journal of Money, Credit and Banking 40 (4), 721-750.

Finn, M. G., December 1999. An equilibrium theory of nominal and real exchange rate comovement. Journal of Monetary Economics 44 (3), 453-475.

Fofana, I., Chitiga, M., Mabugu, R., 2009. Oil prices and the South African economy: A macro-meso-micro analysis. Energy Policy 37 (12), 5509-5518.

Frondel, M., Schmidt, C. M., 2002. The capital-energy controversy: An artifact of cost shares? The Energy Journal 23 (3), 53-79.

Frondel, M., Schmidt, C. M., 2004. Facing the truth about separability: nothing works without energy. Ecological Economics 51, 217-223.

Gali, J., Lopez-Salido, J. D., Valles, J., 2007. Understanding the effects of government spending on consumption. Journal of the European Economic Association 5, 227-270.

Gupta, R., Hartley, F., 2013. The role of asset prices in forecasting inflation and output in south africa. Journal of Emerging Market Finance 12 (3), 239-291.

Gupta, R., Kanda, P., 2015. Does the price of oil help predict inflation in South Africa? historical evidence using a frequency domain approach. Economia Internazionale/International Economics LXVIII (4), 451-467.

Gupta, R., Kotze, K., 2017. The role of oil prices in the forecasts of south african interest rates: A bayesian approach. Energy Economics 61 (1), 270-278.

Gupta, R., Sun, X., 2016. Housing market spillovers in south africa: Evidence from an estimated small open economy dsge model. Department of Economics, University of Pretoria, Working Paper No. 201641.

Gupta, R., Wohar, M., 2017. Forecasting oil and stock returns with a Qual VAR using over 150 years of data. Energy Economics 62 (1), 181-186.

Hamilton, J. D., 1983. Oil and the macroeconomy since world war ii. Journal of Political Economy 91, 228-248.

Hickman, B., Huntington, H., Sweeney, J. (Eds.), 1987. Macroeconomic Impacts of Energy Shocks. North-Holland, Amsterdam.

Hou, K., Mountain, D., Wu, C., 2016. Oil price shocks and their transmission mechanism in an oil-exporting economy: A VAR analysis informed by a DSGE model. Journal of International Money and Finance 68, 21-49.

Jiménez-Rodríguez, R., Sánchez, M., 2005. Oil price shocks and real gdp growth: Empirical evidence for some OECD countries. Applied Economics 37, 201-228. 
Kantor, B. S., Barr, G. D. I., 1986. The impact of a change in the price of petrol on the South African rate of inflation. Journal for Studies in Economics and Econometrics 26, $35-57$.

Kilian, L., 2009. Not all oil price shocks are alike: Disentangling demand and supply shocks in the crude oil market. American Economic Review 99 (3), 1053-1069.

Kilian, L., 2014. Oil price shocks: Causes and consequences. The Annual Review of Resource Economics 6, 133-154.

Kim, I.-M., Loungani, P., 1992. The role of energy in real business cycle models. Journal of Monetary Economics 29 (2), 173-189. URL http://www.sciencedirect.com/science/article/pii/030439329290011P

Kin, S., Courage, M., 2014. The impact of oil prices on the exchange rate in South Africa. Jounal of Economics 5 (2), 193-199.

Kohler, M., 2006. The economic impact of rising energy prices: A constraint on South Africa's growth and poverty reduction opportunities. Paper prepared for the TIPS/DPRU Forum, Johannesburg, 18-20 October 2006.

Lucas Jr, R. E., 1976. Econometric policy evaluation: A critique. Carnegie-Rochester Conference Series on Public Policy 1, 19-46.

McCracken, M. W., 2007. Asymptotics for out-of-sample tests of granger causality. Journal of Econometrics 140, 719-752.

McDonald, S., van Schoor, M., February 2005. A computable general equilibrium analysis of the impact of an oil price increase in South Africa. PROVIDE Working Paper 2005:1, Elsenburg.

Medina, J. P., Soto, C., December 2005. Oil shocks and monetary policy in an estimated DSGE model for a small open economy. Central Bank of Chile, Working Paper No. 353.

Medina, J. P., Soto, C., December 2007. Copper price, fiscal policy and business cycle in chile. Central Bank of Chile Working Papers No. 458.

Medina, J. P., Soto, C., February 2014. Commodity price shocks and imperfectly credible macroeconomic policies in commodity-exporting small open economies. IMF Working Paper, WP/14/33, IMF Institute for Capacity Development.

Monacelli, T., December 2005. Monetary policy in a low pass-through environment. Journal of Money, Credit, and Banking 37 (6), 1047-1066.

Montoro, C., 2012. Oil shocks and optimal monetary policy. Macroeconomic Dynamics 16, $240-277$. 
Mork, K., Hall, R., 1980. Energy prices, inflation and recession 197475. Energy Journal 1, 31-63.

Natal, J.-M., February 2012. Monetary policy response to oil price shocks. Journal of Money, Credit and Banking 44 (1), 53-101.

Nkomo, J. C., 2006. The impact of higher oil prices on southern african countries. Journal of Energy Research in Southern Africa 17 (1), 10-17.

Ortiz, A., Sturzenegger, F., 2007. Estimating SARB's policy reaction rule. South African Journal of Economics 75 (4), 659-680.

Paetz, M., Gupta, R., 2016. Stock price dynamics and the business cycle in an estimated DSGE model for south africa. Journal of International Financial Markets, Institutions and Money 44 (1), 166-182.

Peersman, G., Stevens, A., 2010. Oil demand and supply shocks: an analysis in an estimated DSGE-model. Ghent University, Mimeo.

Rasche, R., Tatom, J., 1977. The effect of the new energy regime on economic capacity, production and prices. Economic Review 52, 2-12.

Ratto, M., 2008. Analysing DSGE models with global sensitivity analysis. Computational Economics 31, 115-139.

Ratto, M., Iskrev, N., 2011. Identification analysis of DSGE models with DYNARE. mimeo. URL https://www.ifk-cfs.de/fileadmin/downloads/events/conferences/ monfispol2011/RATTO_IdentifFinal.pdf

Rondina, F., 2017. The impact of oil price changes in a New Keynesian model of the U.S. economy. Working Papers 1709E, University of Ottawa, Department of Economics.

Rotemberg, J. J., Woodford, M., November 1996. Imperfect competition and the effects of energy price increases on economic activity. Journal of Money, Credit, and Banking 28 (4), $549-577$.

Sánchez, M., September 2011. Oil shocks and endogenous markups: Results from an estimated euro area DSGE model. International Economics and Economic Policy 8 (3), $247-273$.

Schmitt-Grohé, S., Uribe, M., 2003. Closing small open economy models. Journal of International Economics 61, 163-185.

Smets, F., Wouters, R., 2002. Openness, imperfect exchange rate pass-through and monetary policy. Journal of Monetary Economics 49 (5), 913-940.

Smets, F., Wouters, R., 2007. Shocks and frictions in US business cycles: a bayesian approach. American Economic Review 97 (3), 586-606. 
Steinbach, M., Mathuloe, P., Smit, B., 2009. An open economy New Keynesian DSGE model of the South African economy. South African Journal of Economics 77 (2), 207-227.

Swanepoel, J. A., 2006. Do international economic developments affect the South African economy? South African Journal of Economic and Management Sciences 9 (1), 128-148.

Tshepo, M., 2015. Analysing the pass-through effects of oil prices on inflation in South Africa: Granger-causality approach. Biennial Economic Society of South Africa Conference, Cape Town, South Africa.

Vásconez, V. A., Giraud, G., McIsaac, F., Pham, N.-S., 2015. The effects of oil price shocks in a new-keynesian framework with capital accumulation. Energy Policy 86, 844-854.

Wakeford, J., 2006. The impact of oil price shocks on the south african macroeconomy: History and prospects. In: South African Reserve Bank Conference. pp. 95-115.

Wakeford, J., 2012. Implications of global oil depletion for South Africa: vulnerabilities, impacts and transition to sustainability. Ph.D. thesis, Stellenbosch University, South Africa. 


\section{Appendix}

\section{A. The linearized system}

\section{A.1. Aggregate demand}

$$
\begin{aligned}
\hat{c}_{t}^{h} & =\gamma_{c}\left(\eta_{c}-\eta_{o}\right)\left(r \hat{e} r_{t}-\hat{\psi}_{t}^{f}\right)-\left(\gamma_{c}\left(\eta_{c}-\eta_{o}\right)+\eta_{o}\right) \hat{p r}_{t}^{h}+\hat{c}_{t} \\
\hat{c}_{t}^{f} & =\left(1-\gamma_{c}\right)\left(\eta_{c}-\eta_{o}\right) \hat{p r} r_{t}^{h}+\left(\gamma_{c}-\eta_{c}\right)\left(r \hat{e} r_{t}-\hat{\psi}_{t}^{f}\right)+\hat{c}_{t} \\
\hat{o}_{t}^{c} & =-\eta_{o} \hat{p r}_{t}^{o}+\hat{c}_{t} \\
\hat{c}_{t} & =\frac{1}{(1+\phi)} \hat{c}_{t+1}+\frac{\phi}{(1+\phi)} \hat{c}_{t-1}-\frac{(1-\phi)}{\sigma_{c}(1+\phi)}\left(\hat{i}_{t}^{b}-\hat{\pi}_{t+1}+\hat{\mu}_{t}^{b}\right) \\
r \hat{e} r_{t} & =\frac{\sigma_{c}^{*}}{1-\phi^{*}}\left(\hat{c}_{t}^{*}-\phi^{*} \hat{c}_{t-1}^{*}\right)-\frac{\sigma_{c}}{1-\phi}\left(\hat{c}_{t}-\phi \hat{c}_{t-1}\right) .
\end{aligned}
$$

EqA.1 domestic consumption of home goods; EqA.2 domestic consumption of foreign goods; EqA.3 domestic consumption of oil; Eq A.4 Euler eqn; Eq A.5 is the international risk sharing condition (where $\hat{c}_{t}^{*}=\hat{y}_{t}^{*}$ ) ${ }^{25}$

\section{A.1.1. Investment schedule}

$$
\hat{v}_{t}-\hat{k}_{t}=\beta E_{t}\left(\hat{v}_{t+1}-\hat{k}_{t+1}\right)+\frac{\beta R^{k}}{\kappa_{v}} E_{t}\left(\hat{r}_{t+1}^{k}\right)+\frac{\sigma_{c}}{\kappa_{v}}\left(\hat{c}_{t}-\hat{c}_{t+1}\right),
$$

where $R^{k}=1 / \beta-(1-\delta)$.

\section{A.2. Aggregate supply 83 inflation}

A.2.1. (real) wage setting equation:

$$
\begin{aligned}
\hat{w}_{t}= & \Omega \beta E_{t} \hat{w}_{t+1}+\Omega \hat{w}_{t-1}+\Omega \Omega^{*}\left(m \hat{r} s_{t}-\hat{w}_{t}\right) \\
& +\Omega \beta E_{t} \hat{\pi}_{t+1}-\Omega \hat{\pi}_{t}-\Omega \theta_{w} \beta \gamma_{w} \hat{\pi}_{t}+\Omega \gamma_{w} \hat{\pi}_{t-1} .
\end{aligned}
$$

The real wage $\left(\hat{w}_{t}=w_{t}-p_{t}\right)$ setting equation can be re-written in nominal wage inflation form as 26

${ }^{25}$ The UIP condition holds from the Euler equations of the domestic and foreign sectors: $\hat{i}_{t}^{b}=\hat{i}_{t}^{b *}+$ $E_{t}\left[\Delta \hat{\varepsilon}_{t+1}\right]+\hat{\Phi}_{t}$, which implies that the real exchange rate equates the marginal utilities of consumption between the domestic and foreign households.

${ }^{26}$ Log-linearizing Eq. 18 and solving for $\tilde{w}_{t}$ gives the optimal reset wage equation:

$$
\tilde{w}_{t}=\frac{\left(1-\theta_{w} \beta\right)}{\left(1+\xi^{w} \sigma_{n}\right)} E_{t} \sum_{i=0}^{\infty}\left(\theta_{w} \beta\right)^{i}\left(\chi m r s_{t+i}+\xi^{w} \sigma_{n} w_{t+i}+p_{t+i}-\gamma_{w} \pi_{t+i-1}\right)
$$

where $\chi \equiv \frac{W}{M R S^{s} \mu^{w}}$. Combining $($ A.7 with the log-linearized wage index equation 16 gives the aggregate sticky real wage $\left(\hat{w}_{t}=w_{t}-p_{t}\right)$ equation, which we can re-write in nominal wage inflation form as Eq. A.8 


$$
\hat{\pi}_{t}^{w}-\gamma_{w} \hat{\pi}_{t-1}=\beta E_{t} \hat{\pi}_{t+1}^{w}-\theta_{w} \beta \gamma_{w} \hat{\pi}_{t}+\Omega^{*}\left(m \hat{r} s_{t}-\hat{w}_{t}\right)
$$

where $\Omega^{*}=\frac{\left(1-\theta_{w}\right)\left(1-\theta_{w} \beta\right)}{\theta_{w}\left(1+\xi^{w} \sigma_{n}\right)}, \Omega=\frac{1}{(1+\beta)}$, and $m \hat{r} s_{t}=\frac{\sigma_{c}}{1-\phi}\left(\hat{c}_{t}-\phi \hat{c}_{t-1}\right)+\sigma_{n} \hat{n}_{t}$.

A.2.2. Domestic production and inflation (for consumption goods)

$$
\hat{\pi}_{t}^{h}=\frac{\gamma_{p}}{\left(1+\gamma_{p} \beta\right)} \hat{\pi}_{t-1}^{h}+\frac{\beta}{\left(1+\gamma_{p} \beta\right)} E_{t} \hat{\pi}_{t+1}^{h}+\kappa_{h}\left(\hat{m} c_{t}^{h}+\hat{\xi}_{t}^{p}\right),
$$

where $\hat{m} c_{t}^{h}=\hat{\lambda}_{t}$ is the real marginal cost of production, and $\kappa_{h}=\frac{\left(1-\theta_{h}\right)\left(1-\theta_{h} \beta\right)}{\theta_{h}\left(1+\gamma_{p} \beta\right)}$.

$$
\begin{aligned}
& \hat{\lambda}_{t}=\left(\hat{w}_{t}-\hat{p r} r_{t}^{h}\right)-\left(\hat{y}_{t}^{h}-\hat{n}_{t}\right) \\
& \hat{\lambda}_{t}=\hat{r}_{t}^{k}-\left(\hat{y}_{t}^{h}-\nu \hat{k}_{t}-\hat{y} x_{t}\right) \\
& \hat{\lambda}_{t}=\left(\hat{p r} \hat{r}_{t}^{o}-\hat{p r} r_{t}^{h}\right)-\left(\hat{y}_{t}^{h}-\nu \hat{o}_{t}^{h}-\hat{y} x_{t}\right)
\end{aligned}
$$

where $\hat{y} x_{t}=\vartheta(1-\nu) \hat{k}_{t}+(1-\vartheta)(1-\nu) \hat{o}_{t}^{h}$.

$$
\hat{y}_{t}^{h}=\hat{a}_{t}+\alpha \hat{n}_{t}+(1-\alpha) \vartheta \hat{k}_{t}+(1-\alpha)(1-\vartheta) \hat{o}_{t}^{h}
$$

A.2.3. Imported inflation (for foreign consumption goods)

$$
\hat{\pi}_{t}^{f}=\beta E_{t}\left[\hat{\pi}_{t+1}^{f}\right]+\kappa_{f} \hat{\psi}_{t}^{f}
$$

where $\kappa_{f}=\frac{\left(1-\theta_{f}\right)\left(1-\theta_{f} \beta\right)}{\theta_{f}}$, and $\hat{\psi}_{t}^{f}$ measures the l.o.p gap ${ }^{27}$

$$
\begin{aligned}
\hat{\psi}_{t}^{f} & =\hat{\varepsilon}_{t}+\hat{p}_{t}^{f *}-\hat{p}_{t}^{f}, \\
& =r \hat{e} r_{t}-\hat{p} r_{t}^{f} .
\end{aligned}
$$

\section{A.2.4. Inflation aggregation equations}

From the inflation aggregation equations we have:

$$
\begin{aligned}
\hat{\pi}_{t}^{z} & =\left(1-\gamma_{c}\right) \hat{\pi}_{t}^{h}+\gamma_{c} \hat{\pi}_{t}^{f} \\
\hat{\pi}_{t} & =\left(1-\gamma_{o}\right) \hat{\pi}_{t}^{z}+\gamma_{o} \hat{\pi}_{t}^{o} \\
\therefore \hat{\pi}_{t} & =\left(1-\gamma_{o}\right)\left(1-\gamma_{c}\right) \hat{\pi}_{t}^{h}+\left(1-\gamma_{o}\right) \gamma_{c} \hat{\pi}_{t}^{f}+\gamma_{o} \hat{\pi}_{t}^{o} .
\end{aligned}
$$

Eq. A.16 and Eq. A.17 can be re-written as (see Medina and Soto, 2005)

$$
\begin{aligned}
\hat{\pi}_{t}^{z} & =\hat{\pi}_{t}-\frac{\gamma_{o}}{\left(1-\gamma_{o}\right)}\left(\hat{p r}_{t}^{o}-\hat{p r}_{t-1}^{o}\right) \\
0 & =\gamma_{o} \hat{p r}_{t}^{o}+\left(1-\gamma_{o}\right)\left(1-\gamma_{c}\right) \hat{p r}_{t}^{h}+\left(1-\gamma_{o}\right) \gamma_{c}\left(\hat{p r}_{t}^{f}\right) .
\end{aligned}
$$

\footnotetext{
${ }^{27} r \hat{e} r_{t}=\hat{\varepsilon}_{t}+\hat{p}_{t}^{f *}-\hat{p}_{t}$ and $\hat{p} r_{t}^{f}=\hat{p}_{t}^{f}-\hat{p}_{t}$.
} 


\section{A.2.5. Evolution of relative prices}

$$
\begin{aligned}
\hat{p r}_{t}^{h} & =\hat{p r} \hat{t}_{t-1}^{h}+\hat{\pi}_{t}^{h}-\hat{\pi}_{t} \\
\hat{p r} & =\hat{p r}{ }_{t-1}^{f}+\hat{\pi}_{t}^{f}-\hat{\pi}_{t} \\
\hat{p r} r_{t}^{o} & =r \hat{e} r_{t}+\hat{p r} r_{t}^{o *}+\hat{\psi}_{t}^{o} \\
r \hat{e} r_{t} & =r \hat{e} r_{t-1}+\Delta \hat{\varepsilon}_{t}+\hat{\pi}_{t}^{f *}-\hat{\pi}_{t} \\
\hat{\pi}_{t}^{o} & =\hat{p r}_{t}^{o}-\hat{p r}_{t-1}^{o}+\hat{\pi}_{t}, \\
\hat{s}_{t} & =\hat{p r} \hat{p}^{f}-\hat{p r}^{h} \\
\hat{w}_{t} & =\hat{w}_{t-1}+\hat{\pi}_{t}^{w}-\hat{\pi}_{t},
\end{aligned}
$$

where $\hat{p r}_{t}^{o *}$ (the relative (real) foreign price of oil, $\hat{p}_{t}^{o *}-\hat{p}_{t}^{f *}$ ) and $\hat{\psi}_{t}^{o}$ (deviations from l.o.p on relative (real) domestic price of oil, $\hat{p r}_{t}^{o}$ ), are $\mathrm{AR}(1)$ processes ${ }^{28} \mathrm{Eq}$ A.23 is the equation of motion for the relative purchasing power parity condition ${ }^{29}$ Here, we can think of nominal exchange rate changes $\left(\Delta \hat{\varepsilon}_{t}\right)$ as the price adjustment mechanism that maintains equilibrium between foreign and domestic goods markets. We can derive an equation for oil inflation in nominal dollar (i.e., foreign currency) terms:

$$
\hat{\pi}_{t}^{o *}=\hat{p r} r_{t}^{o *}-\hat{p r}{ }_{t-1}^{o *}+\hat{\pi}_{t}^{f *}
$$

where $\hat{p r}_{t}^{o *}$ is a stochastic process capturing shocks to the price of oil relative to the foreign price level. Eq A.27 therefore capture both changes in real oil price movements and the endogenous evolution of price, productivity and risk premium shocks from the foreign economy.

\section{A.2.6. Evolution of capital}

$$
\hat{k}_{t+1}=(1-\delta) \hat{k}_{t}+\delta \hat{v}_{t}
$$

\section{A.2.7. Policy rule}

$$
\hat{i}_{t}^{b}=\rho_{i} \hat{i}_{t-1}^{b}+\left(1-\rho_{i}\right) \kappa_{\pi} \hat{\pi}_{t}+\left(1-\rho_{i}\right) \kappa_{y}\left(\hat{y}_{t}-\hat{y}_{t-1}\right)+\epsilon_{t}^{i}
$$

\section{A.3. Foreign economy}

We assume a large open economy for the foreign market. This allows us to specify the foreign rate, $\hat{i}_{t}^{b *}$, foreign inflation $\hat{\pi}_{t+1}^{*}=\hat{\pi}_{t+1}^{f *}$, and foreign consumption $\hat{y}_{t}^{*}=\hat{c}_{t}^{*}$ according to

\footnotetext{
${ }^{28}$ Specification of stochastic processes in Eq. A.22 is important. It depends on how we treat the price of oil in estimation: if it enters as $\hat{p} r_{t}^{o *}$ then we can separate the shocks; if we introduce as $\hat{p} r_{t}^{o}$, then we must combine them. As we are interested in foreign real oil price shocks we opt for the former.

${ }^{29}$ Derived from $r \hat{e} r_{t+1}=r \hat{e} r_{t}+\left(\hat{i}_{t}^{b}-\hat{\pi}_{t+1}\right)-\left(\hat{i}_{t}^{b *}-\hat{\pi}_{t+1}^{f *}+\hat{\Phi}_{t}\right)$, where $\left(\hat{i}_{t}^{b}-\hat{\pi}_{t+1}\right)$ and $\left(\hat{i}_{t}^{b *}-\hat{\pi}_{t+1}^{f *}\right)$ are the domestic and foreign real interest rates on bonds, i.e., the Fisher equations; $\hat{\Phi}_{t}=\hat{\mu}_{t}^{b *}-\hat{\mu}_{t}^{b}$
} 
the standard 3-equation New-Keynesian model, namely: an IS curve, a Phillips curve, and a Taylor-type policy rate rule.

$$
\begin{gathered}
\hat{y}_{t}^{*}=\frac{1}{\left(1+\phi^{*}\right)} \hat{y}_{t+1}^{*}+\frac{\phi^{*}}{\left(1+\phi^{*}\right)} y_{t-1}^{*}-\frac{\left(1-\phi^{*}\right)}{\sigma_{c}^{*}\left(1+\phi^{*}\right)}\left(\hat{i}_{t}^{b *}-E_{t}\left[\hat{\pi}_{t+1}^{*}\right]+\hat{\mu}_{t}^{b *}\right) \\
\hat{\pi}_{t}^{*}=\frac{\gamma^{*}}{\left(1+\gamma^{*} \beta\right)} \hat{\pi}_{t-1}^{*}+\frac{\beta}{\left(1+\gamma^{*} \beta\right)} E_{t}\left[\hat{\pi}_{t+1}^{*}\right]+\kappa_{*} \hat{m} c_{t}^{*}
\end{gathered}
$$

where $\hat{m} c_{t}^{*}$ is the real marginal cost of production, and $\kappa_{*}=\frac{\left(1-\theta_{*}\right)\left(1-\theta_{*} \beta\right)}{\theta_{*}\left(1+\gamma^{*} \beta\right)}$.

$$
\begin{gathered}
\hat{m} c_{t}^{*}=\left(\frac{\sigma_{c}^{*}}{1-\phi^{*}}+\sigma_{n}^{*}\right) \hat{y}_{t}^{*}-\left(\frac{\sigma_{c}^{*} \phi^{*}}{1-\phi^{*}}\right) \hat{y}_{t-1}^{*}-\left(1+\sigma_{n}^{*}\right) \hat{a}_{t}^{*}, \\
\hat{i}_{t}^{b *}=\rho_{i *} \hat{i}_{t-1}^{b *}+\left(1-\rho_{i *}\right) \kappa_{\pi}^{*} \hat{\pi}_{t}^{*}+\left(1-\rho_{i *}\right) \kappa_{y}^{*}\left(\hat{y}_{t}^{*}-\hat{y}_{t-1}^{*}\right)+\epsilon_{t}^{i *},
\end{gathered}
$$

A.4. Aggregate equilibrium

$$
\begin{aligned}
\hat{y}_{t}^{h} & =\frac{C^{h}}{Y^{h}} \hat{c}_{t}^{h}+\frac{C^{h *}}{Y^{h}} \hat{c}_{t}^{h *} \\
& =\frac{C^{h}}{Y^{h}} \hat{c}_{t}^{h}+\frac{\left(1-C^{h}\right)}{Y^{h}}\left(\hat{y}_{t}^{*}-\xi^{f *}\left(\hat{p r}_{t}^{h}-r \hat{e} r_{t}\right)\right)
\end{aligned}
$$

where $\xi^{f *}$ is the foreign price elasticity of demand for domestic goods (i.e., the change in foreign demand for domestic goods given the foreign price of domestic goods relative to the foreign price of foreign goods).

$$
\begin{aligned}
\hat{y}_{t} & =\frac{C}{Y} \hat{c}_{t}+\frac{V}{Y} \hat{v}_{t}+\frac{X}{Y} \hat{x}_{t}-\frac{M}{Y} \hat{m}_{t} \\
\hat{x}_{t}=\hat{c}_{t}^{h *} & =\hat{y}_{t}^{*}-\xi^{f *}\left(\hat{p r}_{t}^{h}-r \hat{e} r_{t}\right) \\
\hat{m}_{t} & =\frac{C^{f}}{M} \hat{c}_{t}^{f}+\frac{O}{M} \hat{o}_{t} \\
\hat{o}_{t} & =\frac{O^{c}}{O} \hat{o}_{t}^{c}+\frac{O^{h}}{O} \hat{o}_{t}^{h},
\end{aligned}
$$

where $O / M=\left(M-C^{f}\right) / M$.

\section{A.5. Exogenous shocks}

We include 8 shocks in the model. The oil shock to the foreign real price of oil follows as: $\hat{p r_{t}^{o *}}=\rho_{o *} \hat{p r}_{t-1}^{o *}+\epsilon_{t}^{o *}$. For the domestic economy, the monetary policy shock $\left(\epsilon_{t}^{i}\right)$, as given in Eq. A.29, is i.i.d, whereas the domestic technology shock and domestic price markup shock follow $\mathrm{AR}(1)$ processes: $\hat{a}_{t}=\rho_{a} \hat{a}_{t-1}+\epsilon_{t}^{a} ; \hat{\xi}_{t}^{p}=\rho_{p} \hat{\xi}_{t-1}^{p}+\epsilon_{t}^{p}$. The foreign economy follows with an i.i.d monetary policy shock $\left(\epsilon_{t}^{i *}\right)$ and the following supply shock: $\hat{a}_{t}^{*}=\rho_{a *} \hat{a}_{t-1}^{*}+\epsilon_{t}^{a *}$. 
In addition, the risk premium shocks on domestic-currency assets relative to the policy rate and for foreign-currency borrowing abroad (equivalent to a negative demand shocks) are described as follows: $\hat{\mu}_{t}^{b *}=\rho_{b} \hat{\mu}_{t-1}^{b *}+\epsilon_{t}^{b *}$ and $\hat{\mu}_{t}^{b}=\rho_{b} \hat{\mu}_{t-1}^{b}+\epsilon_{t}^{b}$.

\section{B. Data and sources}

Data sources retrieved from the Federal Reserve Bank of St. Louis (FRED), the South African Reserve Bank (SARB), US. Energy Information Administration, Eurostat and OECD.stat:

1. Consumer Price Index of All Items in the United States [CPIAUCSL], United Kingdom [GBRCPIALL], Euro area [EZCCM086NEST], Japan [JPNCPIALL] and in South Africa [ZAFCPIALL] retrieved from FRED (Copyright, 2017, OECD)

2. Real Gross Domestic Product by Expenditure for the United States [GDPC1], United Kingdom [GBQ661S], Euro area [EURSCAB1GQEA19], Japan [JPQ661S] and South Africa [ZAQ661S], retrieved from FRED (Copyright, 2017, OECD)

3. Interest Rates, Government Securities, 3-Month Treasury Bills for United States [Gs3M], United Kingdom [GBM193N], Euro Area [EZQ193N], Japan [JPM193N], and South Africa [ZAM193N] retrieved from FRED (Copyright, 2017, IMF and Eurostat)

4. Population: United States (Civilian Noninstitutional Population) [CNP16OV], Japan (15 and over) [JPQ647S], United Kingdom (Total) [POPNC; GBQ647S], and Euro area (Total) [POPNC; EZQ647S] (Copyright, 2016, OECD)

5. SARB, Balance of payments statistics [KBP5000L - KBP5010L]

6. SARB, Final consumption expenditure by households: Total (PCE) [KBP6007L]

7. SARB, Gross fixed capital formation (Investment) [KBP6009L]

8. Crude Oil Prices: Brent - Europe, Dollars per Barrel, Quarterly, Not Seasonally Adjusted [MCOILBRENTEU]

9. World Development Indicators, Fuel imports (\% of merchandise imports), South Africa [TM.VAL.FUEL.ZS.UN] 


\section{Figures}
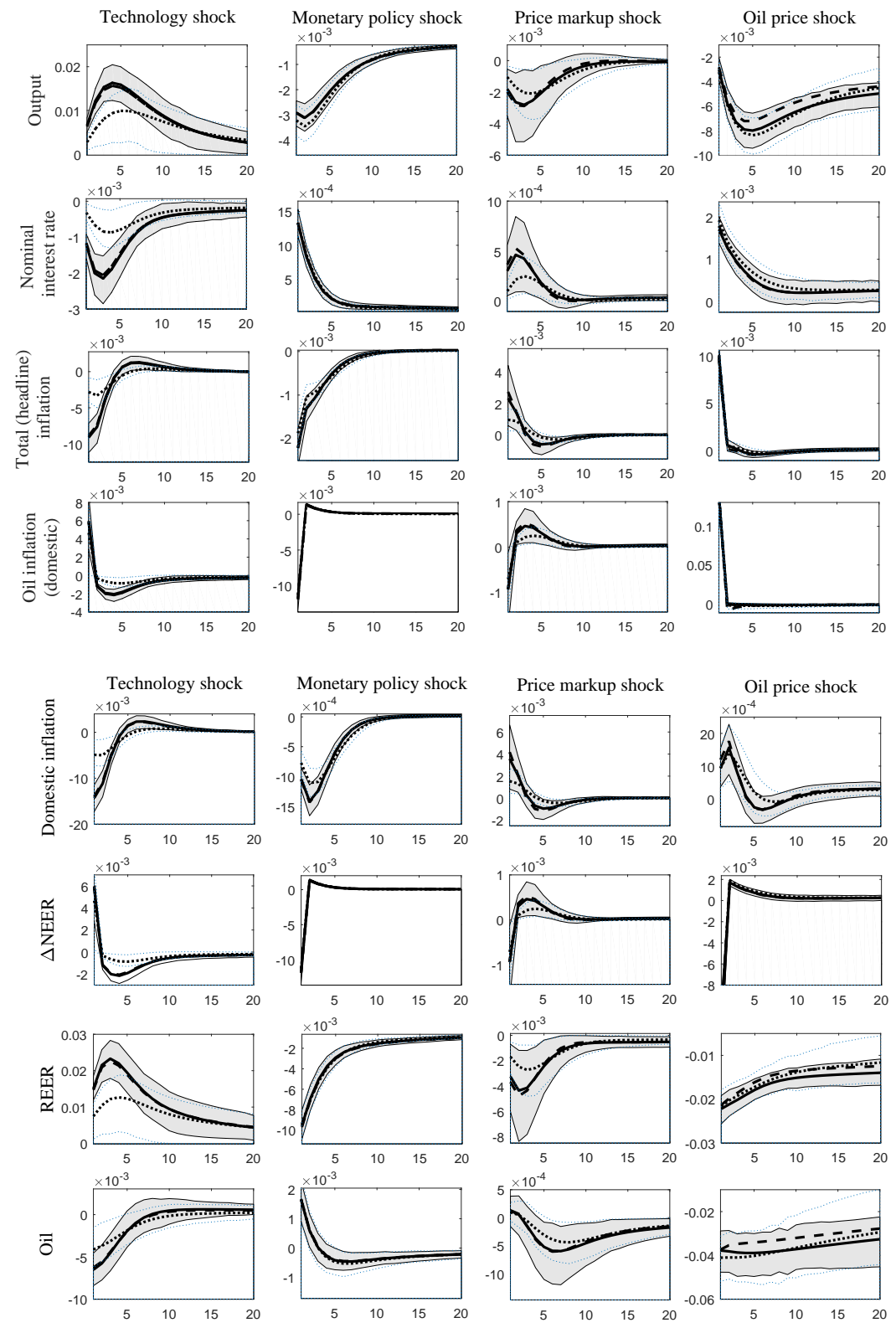

Figure C.1: Impulse responses for oil mod.1 (solid line), mod.2 (dashed line), and mod.3 (dotted line). 90\% highest posterior density interval included for mod.1 and mod.3. 

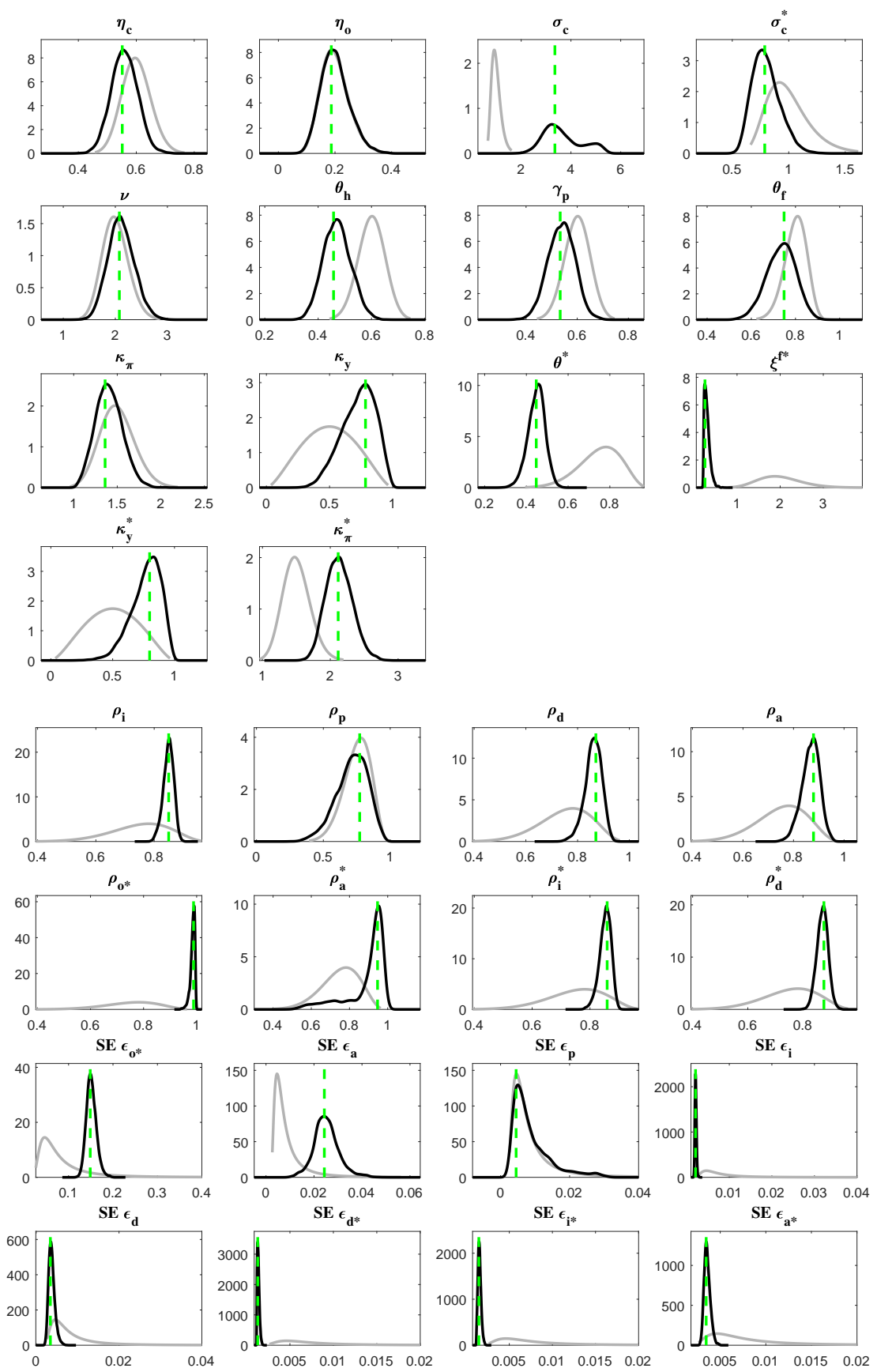

Figure C.2: Prior and Posterior distributions of the estimated parameters. 